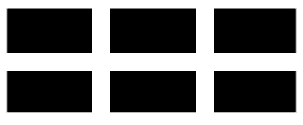

THE WILLIAM DAVIDSON INSTITUTE AT THE UNIVERSITY OF MICHIGAN BUSINESS SCHOOL

Explaining Postcommunist Economic Performance

\author{
By: Lawrence P. King
}

William Davidson Working Paper Number 559

May 2003 
Explaining Postcommunist Economic Performance ${ }^{1}$

Lawrence P. King

Yale University

April 4, 2003 


\section{Abstract: Explaining Postcommunist Economic Performance}

This article critiques neoliberal transition theory from a neoclassical sociological perspective. Neoliberals argue that postcommunist economic failure is the result of inadequate adherence to neoliberal precepts. This paper argues that the neoliberal policy package of "Shock Therapy" (consisting of the radical transition to a market economy through rapid and extensive price and trade liberalization, stringent monetary and fiscal stabilization, and the implementation of a mass privatization program) creates severe supply-and-demand shocks for enterprises, inducing firm failure. This leads to a fiscal crisis for the state, and an erosion of its capacity and bureaucratic character. This in turn reacts back on the enterprise sector, since the state can no longer support the institutions necessary for the effective functioning of capitalist economies. The neoliberal theory is tested against a neoclassical sociological theory by examining the experience of 12 postcommunist countries and two reform Asian communist countries.

Keywords: postcommunist performance, state capacity, liberalization, privatization JEL codes: O1, O5, $\mathrm{P} 2$ 
At the onset of the transition from state socialism to market capitalism, Westerntrained economists provided the postcommunist power elite with the blueprint for constructing capitalism amid the ruins of communism (Stark 1992). They created the Shock Therapy policy package, which, when implemented, devastated the postcommunist economy and weakened the state. A review of the economic history of postcommunist countries demonstrates that "the market" provided no protection for firms during the insertion of postcommunist economies into the global capitalist system, ushering in deindustrialization and impoverishment.

Shock Therapy was, above all else, a Smithian analysis: a successful transition to capitalism could be accomplished by relying on the powers of the invisible hand, unleashed by radical curtailment of the state's involvement in the economy. In Sachs's words, "Markets spring up as soon as central planning bureaucrats vacate the field" (1994: xii). Whenever politically possible, "the market mechanism" would accomplish the tasks that, in the 1960s, most would have expected to be performed by a developmental state.

Where neoliberal reforms were not modified by policy reversals caused by voter backlash, the consequences were severe. The de-modernization of much of the postcommunist world is clear from Table 1. 
Table 1: Economic Performance in Postcommunist Society

\begin{tabular}{|c|c|c|c|c|c|c|}
\hline & $\begin{array}{l}\text { Avg. } \\
\text { GDP Per } \\
\text { Capita } \\
\text { Change } \\
1991- \\
2000 \\
\text { (in 1995 } \\
\text { US\$) }\end{array}$ & $\begin{array}{l}\text { Change in } \\
\text { Male Life } \\
\text { Expectancy } \\
\text { 1989-2000 } \\
\text { (value in } \\
2000 \text { ) }\end{array}$ & $\begin{array}{l}\text { \% of } \\
\text { Population } \\
\text { Below } \\
\text { Poverty } \\
\text { 1993-1995 } \\
\text { (in 1987- } \\
88)\end{array}$ & $\begin{array}{l}\text { \% Exper. } \\
\text { Shortage } \\
\text { of Food } \\
\& / \text { or } \\
\text { Clothes } \\
2000 \text { (in } \\
1989 \text { ) }\end{array}$ & $\begin{array}{l}\text { \% Age- } \\
\text { Appropriate } \\
\text { in Kinder- } \\
\text { garten } 1996 \\
\text { (change } \\
\text { from 1989) }\end{array}$ & $\begin{array}{l}\text { FDI Net } \\
\text { Inflow } \\
\text { Per } \\
\text { Capita } \\
\text { 1990- } \\
2000 \\
\text { (BoP } \\
\text { data in } \\
\text { current } \\
\text { US\$) }\end{array}$ \\
\hline Czech & 0.1 & $+3(71.5)$ & $1(0)$ & NA & $89(-1)$ & $\$ 2,271$ \\
\hline Slovakia & 0.4 & $+2(69.1)$ & $1(0)$ & $15.8(6.5)$ & $75(-17)$ & $\$ 777$ \\
\hline Poland & 3.7 & $+2(71.6)$ & $20(6)$ & $25.7(7.7)$ & $47(-2)$ & $\$ 1,053$ \\
\hline Hungary & 1.3 & $+2(67.1)$ & $4(1)$ & $\begin{array}{l}18.3 \\
(12.5)\end{array}$ & $87(-1)$ & $\$ 2106$ \\
\hline Slovenia & 1.9 & $+3(71.6)$ & $1(0)$ & NA & $65(-7)$ & $\$ 856$ \\
\hline $\begin{array}{l}\text { C.E.E. } \\
\text { Avg. }\end{array}$ & 1.2 & +2.4 & 5.4 & & $73(-5.6)$ & $\$ 1,413$ \\
\hline Russia & -3.5 & $-5(59.0)$ & $50(2)$ & $\begin{array}{l}73.0 \\
(45.1)\end{array}$ & $55(-14)$ & $\$ 141$ \\
\hline Belarus & -0.5 & $-3(62.5)$ & $22(1)$ & NA & $64(+1)$ & $\$ 124$ \\
\hline Ukraine & -7.1 & $-5(63.0)$ & $63(2)$ & NA & $41(-20)$ & $\$ 69$ \\
\hline $\begin{array}{l}\text { FSU } \\
\text { Avg. }\end{array}$ & -3.7 & -4.3 & 45 & & $53(-11)$ & $\$ 111$ \\
\hline Kazakh. & -2.5 & $-4(60.3)$ & $65(5)$ & NA & $24(-31)$ & $\$ 524$ \\
\hline Uzbek. & -2.0 & $+1(66.7)$ & $63(25)$ & NA & $24(-10)$ & $\$ 38$ \\
\hline $\begin{array}{l}\text { CAFSU } \\
\text { Avg. }\end{array}$ & -2.3 & -1.5 & 64 & & $24(-21.5)$ & $\$ 281$ \\
\hline Romania & -1.8 & $-1(66.1)$ & $59(6)$ & $\begin{array}{l}43.9 \\
(26.2)\end{array}$ & $55(-8)$ & $\$ 292$ \\
\hline Bulgaria & -1.4 & $-1(65.1)$ & $15(2)$ & $\begin{array}{l}55.1 \\
(45.7)\end{array}$ & $69(0)$ & $\$ 403$ \\
\hline $\begin{array}{l}\text { E. Eur. } \\
\text { Avg. }\end{array}$ & -1.6 & -1 & 37 & & $62(-4)$ & $\$ 348$ \\
\hline China & 9.0 & $+2(68.6)$ & NA & NA & NA & $\$ 255$ \\
\hline Vietnam & 5.5 & $+4(66.7)$ & NA & NA & NA & $\$ 190$ \\
\hline $\begin{array}{l}\text { E. Asian } \\
\text { Avg. }\end{array}$ & 7.3 & +3 & & & & $\$ 223$ \\
\hline
\end{tabular}

SP $($ Shock Privatization $)=$ Privatized at least $25 \%$ of large SOEs under a mass privatization program within two years.

SL $($ Shock Liberalization $)=$ Liberalized at least $75 \%$ of imports and domestic prices within two years SS $($ Shock Stabilization $)=$ Implemented an IMF approved stabilization package.

GDP and life-expectancy data from World Bank Development Indicators 2001 (CD-ROM); poverty rates from Branko Milanovic. Income, Inequality and Poverty During the Transition from Planned to Market Economy. (Washington, DC.: The World Bank, 1998); kindergarten enrollments from Human Development Report for Central and Eastern Europe and the CIS 1999: 58 (Bratislava: United Nations Development Program); food and clothing deprivation from Kligman and Szelenyi (2002). Policy data from historical summaries. 
Outside of Central Eastern Europe and East Asia reform communism, economic performance has been disastrous. Economic output has declined dramatically, and poverty rates have skyrocketed. Extreme poverty, as measured by a survey that asked respondents if they had recently gone to bed hungry because of lack of food and if they lacked adequate clothing, is startlingly high. A full $73 \%$ of Russian respondents said they either had gone to bed hungry recently and/or had inadequate clothing. This is consistent with the amazingly rapid decline in male life expectancy at birth. By the year 2000 Male life expectancy in Russia was a full five years lower than it was 10 years ago, only 59.0 years, significantly lower than in China (68.64) and even in Vietnam (66.70).

The rest of this paper is divided into two sections. In the first, the competing theoretical claims of the neoliberals' Shock Therapy approach is contrasted with a neoclassical sociological approach. The second presents comparative evidence on the economic performance of the postcommunist world which is consistent with the sociological position and inconsistent with the neoliberal position. The punch line is that the key "switching point" (see Weber 1978) in the brief history of postcommunism was the decision to pursue Shock Therapy -- and especially all three components -- within a relatively brief period. These policies, when carried out in the absence of large-scale foreign direct investment and/or cooperative production arrangements with multinationals, "derails" the postcommunist transition on the way to Western Europeanstyle capitalism. 


\section{Neo-Smithian Transition Theory}

The restructuring of the postcommunist economies along capitalist lines was intended to be guided by market forces, plain and simple. The IMF and the World Bank no longer tolerated the developmental state as they did in the 1960s and 1970s. In its place, the "market" would restructure firms and thus economies. Neoliberal academics and experts argued that, by allowing the market to work its magic, a new efficient set of organizations would replace the deformed inefficient state-owned enterprises (SOEs) inherited from socialism (Sachs 1991: 3; see also Sachs 1996; Frydman, Gray, and Rapaczynski 1996; Kosolowski 1992; Lipton and Sachs 1990; Fischer and Gelb 1991; Blanchard et al. 1993: 10-11; Carlin, Reenen, and Wolfe 1994: 72; see also Spenner et al. 1998). The notion of pursuing an industrial policy, let alone relying on SOEs to spearhead development, "flies in the face of everything we know about the behavior of states around the world" (Frydman, Rapaczynski, and Turkewitz 1997: 85).

The "big-bang" or Shock Therapy policies shared the neoclassical economic assumption of atomized, rational actors without systematic information deficiencies. ${ }^{2}$ Once the incentive structure was correct, everything else would follow (see Murrell 1993; Gowan 1995). As Vaclav Klaus, the architect of the Czech transition and the chief spokesperson for neoliberalism in the region in the first half of the 1990s, stated, "[C]reating the conditions for the market to work and for private institutions to flourish can accomplish the economic and the social transformation ... [people will] change their patterns of behavior and ... adjust their activities rationally and voluntarily if the market provides the right incentives" (quoted in Blejer and Coricelli 1995: 100). 
The neoliberals planned to let the market work by freeing up prices and allowing foreign firms to compete in the domestic economy. Given these "true" price signals, and a stable economic environment created by stabilization (i.e., austerity) programs, the Smithian private actors created by privatization would utilize resources in such a way as to maximize efficiency, and quickly establish a growth trajectory based on each country's “comparative advantage.” By allowing the invisible hand to guide restructuring, Eastern Europe would quickly catch up with the West or, as Sachs puts it, experience a "democratically based rise in living standards" (Sachs 1994: 25).

This Smithian transition strategy won the day: "the majority of countries in the former Soviet Union and in Central and Eastern Europe adopted what can best be described as shock therapy or the big bang approach ...”(UNDP 1999: 30). This was "the most dramatic episode of economic liberalization in economic history" (Murrell 1996: 31), "a landslide victory of the neoliberal project" (Greskovits 1998: 22-23). Of course, things haven't turned out the way the neoliberals thought they would, as all but the most outlandishly Panglossian takes on the Former Soviet Union (FSU) see it as an unmitigated disaster.

The neoliberal explanation for the obvious failure of Russia and other postcommunist countries is that they did not adequately implement the Shock Therapy package. A failure to stabilize (Åslund, Boone, and Johnson 1996; de Melo, Denizer, and Gelb 1996; Fisher, Sahay, and Vegh 1996; Sachs and Warner 1996; Sachs 1997) and to carry out price and trade-liberalization policies (de Melo and Gelb 1996; Selowsky and Martin 1997) were identified as causes of poor performance. In addition, poor outcomes were explained by the corrupt behavior of elites and the maintenance of public finance 
(Johnson, Kaufmann, and Shleifer 1997). Indeed, this is the position taken in the official publications of the World Bank and the European Bank for Reconstruction and Development (see EBRD 1999). For some neoliberal observers, failures are the result not of bad policies but of the "cronyism" that is seen as implicitly endogenous to a nation's culture.

I start from a neoclassical sociological position, building on the Marxian and Weberian understandings of capitalism. In this tradition, successful capitalist development requires not just markets but capitalist social-property rights (see Brenner 1986) and a strong bureaucratic state (see Weber 1978; Evans and Rauch 1999). From this perspective, the radically anti-statist Shock Therapy package does more harm than good, because it weakens the state. As a result, it was precisely the Shock Therapy policies implemented by neoliberals that resulted in the de-modernization and impoverishment of large parts of the postcommunist world. Although neoliberals are correct in their view that "corruption" is intimately connected to economic activity in postcommunist society, in many important ways this corruption is a by-product of Shock Therapy itself, as will be explained below. In my sociological analysis, corruption is a by-product of the transformation of the bureaucratic state into a patrimonial one, in which personalistic networks permeate the state, and the separation of the officeholder from the office becomes blurred.

Of course, other factors contribute to postcommunist performance. Foreign direct investment (FDI) confers enormous advantages in terms of securing investment capital, technology transfer, and access to Western markets (see King 2000; 2001a, 2001b; King and Varadi 2002). ${ }^{3}$ From the neoclassical sociological position, this is likely stemming 
from the fact that MNCs "transplant" capitalist social-property relations in the host country. ${ }^{4}$ Those countries in the postcommunist world which have been able to avoid a Russian-style debacle and resume growth trajectories have been able to do this because their firms managed to insert themselves into global networks producing high valueadded manufactured goods. So far, central Eastern Europe and Estonia have been able to avoid the fate of the Soviet Union only because of Western investments and coproduction agreements. This position is not unique to the neoclassical sociological position, since many neoliberals are also boosters of FDI.

Another factor that is important in explaining the variation in growth of postcommunist economies from the neoclassical sociological position is the "advantage of lateness," or the initial level of development; in particular, the extent of industrialization. The advantage of switching resources from low-productivity traditional agriculture to a system of rural industry provides enormous one-time gains in labor productivity, since human muscle is greatly multiplied when put to work on machines. Conversely, once industrialization has been completed, more developed countries should have a greater stock of human capital and more developed infrastructure, and therefore should have an advantage in global markets relative to less developed societies. Table 2 provides data on some "initial conditions" of countries in the postcommunist world. Again, although there is some disagreement with the neoliberal camp, most neoliberal economists would agree with this position. 
Table 2: Initial Conditions

\begin{tabular}{|c|c|c|c|c|c|c|}
\hline & $\begin{array}{l}\text { Population } \\
1989 \\
\text { (millions) }\end{array}$ & $\begin{array}{l}\text { GDP Per } \\
\text { Capita } \\
1990 \text { in } \\
\text { constant } \\
1995 \\
\text { US\$ }\end{array}$ & $\begin{array}{l}\text { \% Empl. in } \\
\text { Agriculture } \\
1989\end{array}$ & $\begin{array}{l}\text { Trade } \\
\text { with } \\
\text { CMEA } \\
\text { as } \% \\
\text { GDP } \\
1990\end{array}$ & $\begin{array}{l}\text { External } \\
\text { Debt } 1989 \\
\text { Per Capita } \\
\text { current } \\
\text { US\$ }\end{array}$ & $\begin{array}{l}\text { \% Age- } \\
\text { Appropriate } \\
\text { in Kinder- } \\
\text { garten } 1989\end{array}$ \\
\hline Czech & 10 & $\$ 5,270$ & 12 & $6.0 \%$ & $\$ 636$ & 90 \\
\hline Slovakia & 5 & $\$ 4,048$ & 13 & $6.0 \%$ & $\$ 365$ & 92 \\
\hline Poland & 38 & $\$ 2,990$ & 25 & $8.4 \%$ & $\$ 1,134$ & 49 \\
\hline Hungary & 10 & $\$ 4,857$ & 19 & $13.7 \%$ & $\$ 2,040$ & 86 \\
\hline Slovenia & 2 & $\$ 9,659$ & 11 & $4.0 \%$ & NA & 72 \\
\hline Russia & 148 & $\$ 3,666$ & 14 & $11.1 \%$ & $\$ 364$ & 69 \\
\hline Belarus & 10 & $\$ 3,057$ & 22 & $41.0 \%$ & $\mathrm{NA}$ & 65 \\
\hline Ukraine & 52 & $\$ 1,969$ & 19 & $23.8 \%$ & $\$ 11$ & 61 \\
\hline Kazakh. & 16 & $\$ 1,995$ & 22 & $20.8 \%$ & $\$ 2$ & 55 \\
\hline Uzbek. & 20 & $\$ 611$ & 39 & $25.5 \%$ & $\$ 3$ & 34 \\
\hline Romania & 23 & $\$ 1,702$ & 28 & $16.8 \%$ & $\$ 473$ & 63 \\
\hline Bulgaria & 9 & $\$ 1,716$ & 19 & $16.1 \%$ & $\$ 1,126$ & 69 \\
\hline China & 1,119 & $\$ 349$ & 60 & $2.3 \%$ & $\$ 40$ & NA \\
\hline Vietnam & 65 & $\$ 206$ & 75 & $15.0 \%$ & $\$ 319$ & NA \\
\hline
\end{tabular}

For \% in agriculture, Czech Republic, Russia, Kazakhstan, Uzbekistan data is for 1990. For Slovakia and Vietnam, data is for 1991, and for Slovenia data is for 1993.

For debt, Kazakhstan and Uzbekistan data is for 1992, Ukraine data is for 1993.

Source: Population, GDP, agriculture, and external-debt data from World Bank 2001. CMEA trade data from De Melo et al. 2001. Kindergarten data from UNDP 1999. Policy data from historical summaries.

\section{The Neoclassical Sociological Theory of the Transition to Capitalism in Postcommunist Society: Shock Therapy as Generating De-Modernization}

Whereas the neoliberals advocate Shock Therapy, including the rapid

privatization of large state-owned enterprises (SOE), the sociological theory of transition

posits that these policies will create supply-and-demand shocks that devastate the

financial position of postcommunist firms. These firms are subsequently unable to

restructure themselves to be competitive on international markets or the liberalized

domestic market. As output declines, so do taxes, creating a severe fiscal crisis of the

$\underline{\text { state, which in turn leads to the weakening of its bureaucratic character and the erosion of }}$ 
its support for the institutions that are necessary for modern capitalist development. The $\underline{\text { result is a system of capitalist property relations (albeit with a significant non-capitalist }}$ sphere) without a bureaucratic state. Rather than locking in "market reforms," the neoliberal policy package managed to lock in a type of capitalism that produces demodernization. In other words, Shock Therapy induced a new equilibrium -- one that is incapable of generating significant investment and thus dynamic growth, and instead brings about an "involutionary" outcome (Burawoy 1996).

\section{The Three Shocks}

The negative shocks to the domestic economy which follow rapid liberalization of prices and foreign trade, as well as the shock associated with the austerity of "stabilization" programs, have been extensively discussed by critics of the Washington Consensus (the most prominent is Nobel Laureate Joseph Stiglitz 2002; see also Gowan 1995, 1999; Andor and Summers 1998; Chussodovsky 1997; Amsden, Kochanowicz, and Taylor 1994; UNDP 1999: 29). Rapid price deregulation, given the often monopolistic structure of Soviet-style economies, will lead to a rapid increase in the prices of inputs, creating an enormous supply shock as producers are unable to afford adequate levels of necessary inputs. In addition, the wholesale liberalization of imports created a large drop in aggregate demand for domestic producers, since they now faced global competitors -some were more technologically advanced, and others had cheaper labor.

The shock that accompanies the fiscal and monetary austerity of "stabilization" packages is also well documented. With tight money, government subsidies cut, and 
credit dramatically more expensive, most firms run into severe cash-flow problems and a shortage of capital for investments and even day-to-day operations.

There was also the devastating shock resulting from the political destruction of the old Warsaw Pact CMEA (or COMECON) trading system. For many states, a vast majority of exports and imports were from the former CMEA, accounting for a huge amount of economic activity, as shown in Table 2 . The breakdown of this trading system therefore disrupted supply chains and created a gigantic loss of markets.

In addition to these shocks, this paper adds the shocks resulting from large-scale privatization, a pillar of the neoliberal package which is not often directly criticized. My neoclassical sociological account of privatization distinguishes between two different types: that of small enterprises and that of large and medium-sized enterprises. The rapid privatization of small and some medium-sized businesses is beneficial, because it provides a superior incentive structure for those in control of these enterprises. Large SOEs, however, cannot be privatized rapidly without unacceptable costs. King has refered to the neoliberal policy of rapid privatization of large enterprises via mass privatization techniques as "shock privatization" (2003). Shock privatization creates severe direct and indirect supply-and-demand shocks for enterprises. ${ }^{5}$ Most important, shock privatization means that the resulting private corporation will not have an owner or owners with sufficient resources to restructure the company. This is, of course, a consequence of attempting to "make capitalism without capitalists" (Eyale, Szelenyi, and Townsley 1998), and is probably the single biggest negative effect of shock privatization. A typical large postcommunist firm, when it begins its life as a privatized enterprise, will face the devastating crises induced by the destruction of the CMEA trading system, as 
well as stabilization and liberalization shocks. Without any capital to carry out desperately needed restructuring, and without the injection of any new managerial talent, many firms found themselves in untenable positions. It is only logical that owners, managers, and workers, unable to work cooperatively through the firm to better their common cause, would look to find solutions to their personal problems -- in this case, their quest to accumulate wealth and survive the transition. Shock privatization also frequently created outside owners with very poor arrangements to monitor firm managers or even to monitor other (typically inside) owners. This was virtually inevitable, since there was almost none of the enormous business infrastructure (Elson 1991), or the protection of shareholder rights, that help "make markets" in advanced capitalist systems. The combination of these two conditions led to large amounts of asset stripping in the postcommunist economy, wreaking havoc on the functioning of many firms. This is a paradox from the neoliberal perspective: while involving the state in the economy is allegedly a recipe for rent-seeking behavior, not involving the state in the transition creates an environment that encourages corruption (see King 2001a, 2001b).

All of these effects combine to create newly privatized firms that were unable to carry out desperately needed restructuring (they had often experienced a long period of decline or had never been modernized). Not only could these firms not afford to meaningfully restructure; they also suffered from severe financial crises. Firms responded in a number of ways. First, there was a huge decrease in paid wages, made primarily through arrears but also through payment in kind. Firms often resorted to providing workers with direct access to the means of subsistence (typically via garden plots and/or collective potato farming) as a means of keeping their workers (Southworth 2001; King 
2002). As Table 3 shows, in 1999 many firms throughout the region still had wage arrears. Second, firms reduced their demand for inputs. This drop in demand was led by the drop in investments. As Table 3 also indicates, there was a huge decline in gross capital formation in constant dollars throughout the postcommunist world outside of Central Europe and East Asia. By the end of Russia's mass privatization program in 1994 , investment was only $30 \%$ of its 1990 level. By 2000 , it was a dismal $18 \%$ of its 1990 level, the same level of decline as in Ukraine.

These three shocks -- swift and extensive liberalization, stabilization, and mass privatization -- all weaken firms. When these shocks overwhelm upstream producers of crucial industrial inputs, additional supply shocks occur for downstream industries. Many industrial-supply firms had developed what Williamson calls "asset specific knowledge"; that is, they produced goods with the special knowledge of the specific needs of their purchaser (Williamson 1975). These types of suppliers will be very difficult or impossible to replace in the short term. Even if the firm finds a replacement, it will probably be a foreign supplier, and the cost may well be prohibitive even if the firm has access to credit to finance the purchase.

These direct supply-and-demand shocks create additional shocks by weakening the state. As firms entered into financial crisis and technical bankruptcy, the first thing to go was often their payment of taxes, which at any rate were contracting along with the economy. In Russia, for example, receipts of the consolidated state budget declined from 41\% of GDP in 1990 to only $26.8 \%$ in 1997 (Vorobyov and Zhukov 2000: 5). This had the rather immediate and obvious effect of drastically reducing state orders from enterprises -- or, in many cases, the orders were maintained but the state stopped paying 
(see King 2002). As Table 3 indicates, the decline in total government consumption is generalized throughout the postcommunist world outside of Central Europe and East Asia. This loss of sales revenues from the state constitutes another major demand shock for firms.

This loss of revenues, when combined with the anti-statist ideology of the neoliberals, quickly led to a lack of state support for the basic institutions that enable firms to successfully restructure by raising their quality and changing their product line so that they can compete in the world market. An important instance of this occurs when the state stops supporting the educational institutions that turn out skilled manpower, leading to a crisis for many firms. Of particular importance is the production of experts with scientific credentials by local polytechnic institutes. In only two years (from 1993 to 1995), the number of technicians in R. \& D. per million of the Russian population fell from 905 to 688, a drop of just under 24\% (World Bank 1999). While some of this is brain drain, case-study data indicates that much is also the result of a shortage of new technicians (King 2002). Table 3 shows a measure of the decline of scientists during the 1990s. Russia's level fell by 19\% from 1994 to 1999, after the biggest decline must already have occurred. Similarly, Ukraine's level declined by a full 36\% from 1995 to 1999, after what also had to be enormous earlier declines. This decline in education affected not only institutions of higher learning but primary education as well, as indicated in the decline of the proportion of children attending kindergarten, which is reported in Table 1. Thus, it looks like the shortage of skilled manpower will only intensify in the future. 
As a result of widespread financial crises, firms up and down commodity chains are unable to get the money or credit they need in order to continue production. Rather than go out of business, however, managers reactivate old "horizontal" ties (or generate new ones) to managers at other firms that functioned to compensate for the scarcity of inputs in the shortage economy (see Kornai 1980). These networks now function to aid in production, given the absence of money and credit in the new capitalist economy, and the network ties allow the firms to withdraw from the market through inter-enterprise arrears, debt-swaps, and barter (see David Woodruff [1990] for an outstanding account of these processes in Russia). Table 3 lists the extent of barter in 2000, based on a firm-level sample conducted by the World Bank and the EBRD. Barter decreases the efficiency of these transactions (because typically a middleman must be used), shields firms from market pressures (because business partners are based on network ties, not price considerations), and makes taxation highly problematic (because it makes it easy to conceal transactions from the state, since in-kind taxes, which are difficult and expensive to collect anyway, are easy to overvalue when they are paid). 
Table 3: Firm Behavior and Restructuring

\begin{tabular}{|l|l|l|l|l|l|}
\hline & $\begin{array}{l}\text { \% of } \\
\text { Firms } \\
\text { with at } \\
\text { Least } \\
25 \% \\
\text { Turnover } \\
\text { in Barter }\end{array}$ & $\begin{array}{l}\text { Fof } \\
\text { Firms } \\
\text { Overdue } \\
\text { Wages }\end{array}$ & $\begin{array}{l}\text { Change in } \\
\text { Gross Cap } \\
\text { Formation } \\
1990-2000 \\
\text { constant } \\
1995 \text { US\$ }\end{array}$ & $\begin{array}{l}\text { Change in } \\
\text { Final Gov. } \\
\text { Consumption } \\
1990-2000 \\
\text { constant 1995 } \\
\text { US\$ }\end{array}$ & $\begin{array}{l}\text { Change in } \\
\text { Scientists } \\
\text { and } \\
\text { Engineers } \\
\text { in R. \& D. } \\
\text { per mill. } \\
1992-99\end{array}$ \\
\hline Czech & $2.7 \%$ & $31.0 \%$ & $+24 \%$ & $-23.0 \%$ & $-32 \%$ \\
\hline Slovakia & $20.0 \%$ & $31.6 \%$ & $+39 \%$ & $-2.7 \%$ & $-15 \%$ \\
\hline Poland & $21.8 \%$ & $17.9 \%$ & $+92 \%$ & $+16.7 \%$ & $+19 \%$ \\
\hline Hungary & $0.0 \%$ & $4.8 \%$ & $+83 \%$ & $+16.7 \%$ & $+5 \%$ \\
\hline Slovenia & $21.0 \%$ & $22.6 \%$ & $+121 \%$ & $+33.8 \%$ & $-25 \%$ \\
\hline & & & & & $-25 \%$ \\
\hline Russia & $33.9 \%$ & $36.8 \%$ & $-82 \%$ & $-25.5 \%$ & $-29 \%$ \\
\hline Belarus & $15.1 \%$ & $48.2 \%$ & $-82 \%$ & $-19.3 \%$ & $-30 \%$ \\
\hline Ukraine & $31.8 \%$ & $23.8 \%$ & $-46 \%$ & $-27.2 \%$ & $-26 \%$ \\
\hline & & & & & NA \\
\hline Kazakh. & $21.8 \%$ & $29.5 \%$ & $-83 \%$ & $-39.0 \%$ & NA \\
\hline Uzbek. & $12.5 \%$ & $33.3 \%$ & NA & NA & \\
\hline & & & & & NA \\
\hline Romania & $7.2 \%$ & $12.5 \%$ & $-46 \%$ & $+16.2 \%$ & $-71 \%$ \\
\hline Bulgaria & $3.0 \%$ & $8.1 \%$ & $-34 \%$ & $-56.4 \%$ & \\
\hline & & & & & $+30 \%$ \\
\hline China & NA & NA & $+184 \%$ & $+166.1 \%$ & NA \\
\hline Vietnam & NA & NA & $+455 \%$ & $+78.0 \%$ & \\
\hline
\end{tabular}

Change in scientists and engineers in Slovenia 1992-1998, Russia 1995-1999, Ukraine 1995-1999, Belarus 1992-1996, China 1994-1996. Policy data from historical summaries presented below. Barter and wages from the World Bank's BEEPS survey. Capital formation, government consumption, and scientist and engineer data from World Bank 2002 (CD-ROM).

The loss of tax revenue from enterprise failure, exacerbated by the rise of hard-totax barter, inevitably weakened the state. As the state was increasingly unable to meet its formal obligations, it began to break down. Poorly paid (or unpaid) state officials are easily corrupted, and the bureaucratic nature of the state decomposed. It became riddled by reactivated (as well as new) patron-client ties between government officials and businessmen. Private market success came to depend to a great extent on arbitrary political decisions and the exercise of private force. 
It is notoriously difficult to provide a reliable and valid measure of the bureaucratic nature of the state or of state capacity. Table 4 provides several attempts at such measures. The EBRD Governance Indicator is a composite score ranging from 1 to 3, taken from the World Bank's Business Environment and Enterprise Performance Survey, that averages firms' perceived hindrance resulting from microeconomic factors, macroeconomic factors, physical infrastructure, and law and order (EBRD 1999: 116). Of course, as will be argued below, we should use composite indicators with great caution. Still, this indicator represents something -- at the very least, the reported perceptions of the provision of infrastructural support and the bureaucratic nature of the state (it measures bureaucracy because it gets at the impersonal application of formal rules and regulations, and the separation of the office from the officeholder [Weber 1978]). ${ }^{6}$

Another measure is the tax revenue as a percentage of GDP, the idea being that a stronger state can extract more resources from society than a weaker state can. While longitudinal data on revenues would be best, the World Bank doesn't report tax revenue for most transition states prior to 1994, and thus it is impossible to discern the change in revenues during the crucial period from the system change until $1994 .^{7}$ The security of property-rights values are taken from the World Bank's World Business Environment Survey, which asked firms, "To what degree do you agree that the legal system will uphold contracts and property rights?" The score is the combined answers of "Strongly disagree" and "Disagree." The higher the score, the lower the perceived bureaucratic nature of the state.

Change over time in state capacity is also captured by the increase in registered total crimes: the argument being that a state with greater capacity can prevent or deter 
more crime than a state with less capacity. However, crime rates are clearly very much a reflection of state capacity: in weaker states, fewer crimes will be recorded, and they are likely to be more serious and violent (UNDP 1999: 23). In a weak state like Russia, for example, "recorded crime in the federation might be no more than one quarter to one third of total crime" (UNDP 1999: 23). Thus, comparisons within regions (which are likely to have similar overall levels of state capacity) are more valid measures of state capacity than comparisons across regions.

These indicators, while very far from perfect, give us some purchase on relative state capacity or strength of bureaucracy. A startling pattern in the data is that, in regional comparisons, those countries that implemented mass privatization programs had worse state capacity and less secure property rights than those which privatized in other ways. The major exception to this pattern is Russian crime rates, which are substantially below their true level. 
Table 4: Measures of State Capacity, Security of Property Rights, and Mass Privatization Programs

\begin{tabular}{|c|c|c|c|c|c|}
\hline & $\begin{array}{l}\text { Neoliberal } \\
\text { Reforms } \\
\text { SP/SL/SS }\end{array}$ & $\begin{array}{l}\text { Tax Rev. as } \\
\text { \% GDP } \\
1994\end{array}$ & $\begin{array}{l}\text { \% Above } \\
\text { Regional } \\
\text { Avg. Increase } \\
\text { in Registered } \\
\text { Total Crime } \\
\text { 1989-1996 }\end{array}$ & $\begin{array}{l}\text { EBRD } \\
\text { Governance } \\
\text { Index (1-3) } \\
1999\end{array}$ & $\begin{array}{l}\text { Insecure } \\
\text { Property } \\
\text { Rights } \\
1999\end{array}$ \\
\hline Czech & "SP/SL/SS & 33 & 78 & 1.59 & 23.3 \\
\hline Slovakia & SL/SS & 35 (1996) & 17 & 1.65 & 14.0 \\
\hline Poland & SL/SS & 35 & -11 & 1.69 & 10.3 \\
\hline Hungary & SL/SS & 38 & 18 & 1.98 & 12.0 \\
\hline Slovenia & SL/SS & 39 & -4.2 & 1.95 & 11.4 \\
\hline Russia & SP/SL/SS & 19 & -17 & 1.16 & 41.6 \\
\hline Belarus & & 33 & 3.2 & 1.57 & 30.4 \\
\hline Ukraine & SP/SL/SS & 22 (1999) & 9.2 & 1.24 & 44.0 \\
\hline Kazakh. & SP/SL/SS & 14 (1997) & 158 & 1.27 & 31.0 \\
\hline Uzbek. & & NA & -60 & 1.83 & 9.6 \\
\hline Romania & SP/SL/SS & 26 & 32 & 1.07 & 21.6 \\
\hline Bulgaria & SL/SS & 30 & -32 & 1.38 & 20.0 \\
\hline China & & 8 & NA & NA & 11.0 \\
\hline Vietnam & SL/SS & 19 & NA & $\mathrm{NA}$ & $\mathrm{NA}$ \\
\hline
\end{tabular}

SP $($ Shock Privatization $)=$ Privatized at least $25 \%$ of large SOEs under a mass privatization program within two years.

SL (Shock Liberalization) $=$ Liberalized at least $75 \%$ of imports and domestic prices within two years. SS $($ Shock Stabilization $)=$ Implemented an IMF approved stabilization package.

Insecure property rights is the percentage in the World Bank's World Business Environment survey that reported that they disagreed in most cases or strongly disagreed that the legal system will uphold contract and property rights. Governance Index from World Bank 1999; revenue data from World Bank 2002 (CDROM). Crime rates from UNDP 1999: 24. Transition policies from historical narratives.

Putting all of these causal arguments together, we see the disadvantages from the full package of Shock Therapy for firm performance, as well as the indirect effects on state capacity. Failing firms and a failing state creates a vicious cycle of enterprise failure and bureaucratic breakdown, resulting in what Burawoy calls "involution" (1996) as wealth is pumped out of the system. Figure 1 captures the causality in this circle. 
Figure 1: The Vicious Cycle of Enterprise and State Failure Created by Shock Therapy

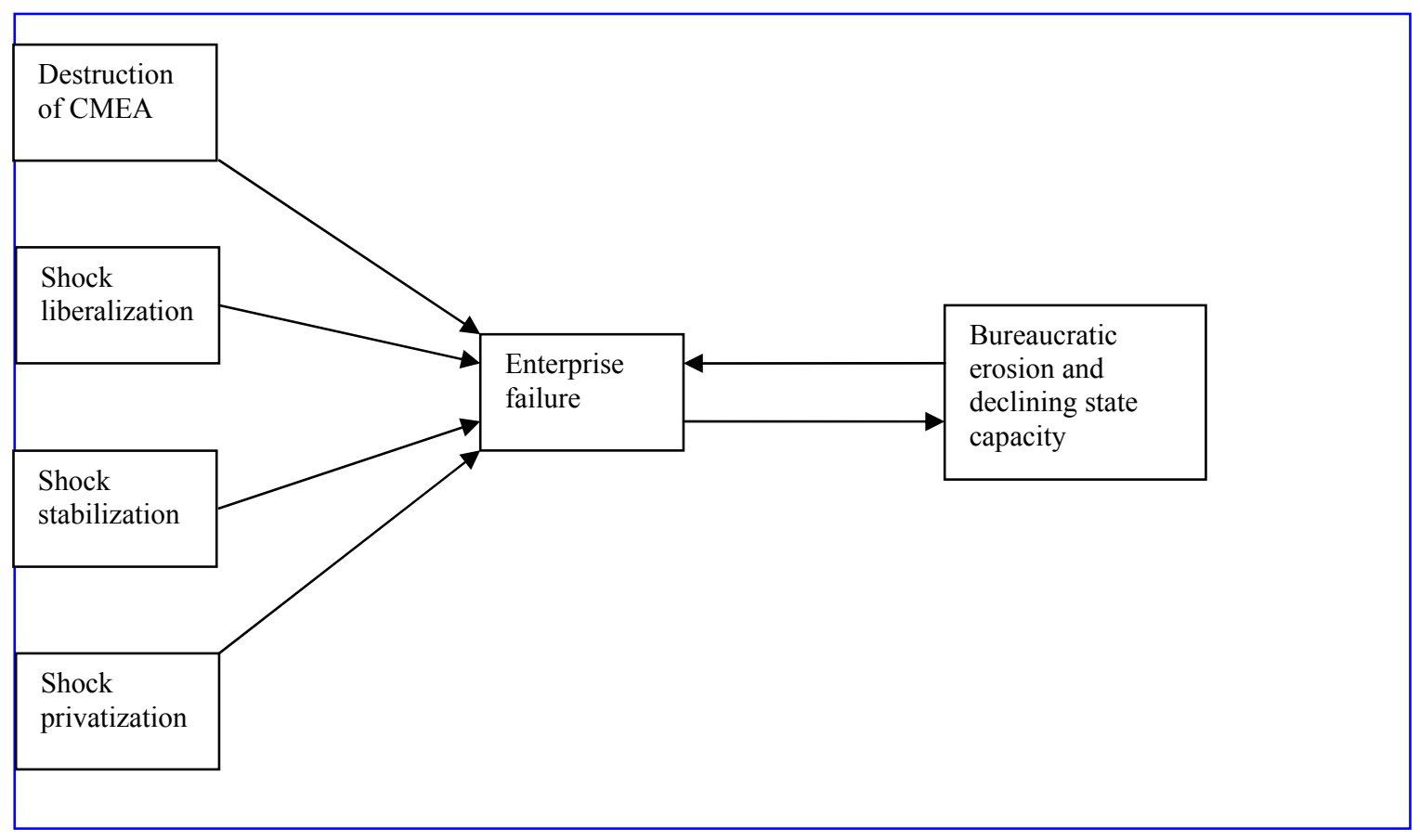

Rather than a system of rational modern capitalism emerging in the Former Soviet Union and much of Eastern Europe, a system of "patrimonial capitalism" seems to have taken root (King 2002; King and Szelenyi 2003). Following Weber (1978), this is a system in which extensive personal networks link (1) state elites and enterprise owners (political capitalism), (2) enterprise managers and their employees (merging workers with the means of production and subsistence), and (3) managers in upstream and downstream companies (non-market mechanisms of exchange). It is also characterized by a nonbureaucratic state. ${ }^{8}$

To the extent that firms can retreat from product markets via horizontal networks with other firms, and from labor markets through the binding of workers to the enterprise by the direct provision of the means of subsistence, capitalists will not be forced to 
reinvest in the means of production to maximize the price-cost ratio. Indeed, given the pervasiveness of political capitalism and the non-bureaucratic nature of the state, such a strategy will be risky. Rather, it is more rational to invest resources to maximize political power (see Brenner's notion of "political accumulation" [1976]), or to "capture the financial flow" and channel as much money out of the country into private bank accounts as possible. By all indications, this is what has been, and still is, happening in Russia on an enormous scale. "[T]he dimensions of capital flight from Russia is about $\$ 40$ billion a year," an amount, coincidentally, that is about equal to the extremely high level of foreign investment in China in the late 1990s (Golovachev 2002).

\section{The Empirical Record}

A comparison of the reform experience of the central Eastern European countries (Hungary, the former Czechoslovakia, Poland, and Slovenia) and the biggest postcommunist states (Russia, Ukraine, Belarus, Kazakhstan, and Uzbekistan), along with East Asian reform-communist systems (China and Vietnam), reveals a very strong pattern that is almost completely inconsistent with neoliberal theory and completely consistent with sociological theory. Owing to space considerations, this paper does not discuss all cases. Most of the unexamined cases are quite small -- Moldova (population: 4 million), Armenia (4 million), Azerbaijan (8 million), Croatia (4 million), Serbia (11 million), Georgia (5 million), Macedonia (2 million), Tajikistan (6 million) -- and have experienced very serious external or internal wars, events that are likely to overwhelm any effect of economic policy on economic performance. 
The remaining unanalyzed states are also very small, and were very dependent on imports and exports from Russia, as can be seen by the ratio of imports and exports to the CMEA as a percentage of GDP in 1990: Turkmenistan (population: 5.2 million, and 33.0\%), Kyrgyzstan (4.9 million and 27.7\%), Lithuania (3.7 million and 40.9\%), Latvia (2.4 million and 36.7\%), Estonia (1.4 million and 30.2\%), Mongolia (2.4 million and 31\%). Albania (3.4 million and 6.6\%), although not greatly influenced by the collapse of CMEA trade and Russia, was severely affected by the Kosovo crisis (the country was inundated by more than 450,000 refugees). Generally, the smaller the country, the greater the chance that it will be even more dependent on the fate of the Russian economy, or that it is able to get enough FDI to partially reorient the economy toward manufacturing exports to the West (as seems to be happening in the Baltic States, most prominently Estonia). ${ }^{9}$ Thus, the less likely domestic economic policy will have a major effect on performance.

\section{Russia Compared with China: Neoliberal Versus Gradualist and Statist Transition Policies}

Looking first at the two biggest cases of postcommunist transformation broadly conceived, China and Russia, we see a pattern that is impossible to square with neoliberal theory. Russia's transition policy was crafted and implemented by radical neoliberal reformers with extremely close working relationships with Jeffrey Sachs and other leading neoclassical theorists (see Wedel 2001: 123-174). Yeltsin and the young reformers led by Gaidar and Chubais implemented all three elements of the Shock Therapy package in spectacular fashion. China, in contrast, systematically violated every 
neoliberal precept. China's vastly superior performance, as compared with Russia's, is thus inconsistent with neoliberal theory.

In Russia, in January 1992, “[a] radical reform package focusing on economic liberalization and privatization was adopted ..." (EBRD 1996: 169). This also included a stabilization policy, initiated by Yegor Gaidar (the acting prime minister in 1991-92), that is justly famous. "An extraordinary improvement in the budget balance -- a text book example -- was accomplished. Arms procurement was initially cut by 85 percent, ... Many subsidies were cut and state investments were minimized.... The old Soviet government administration had also been radically reduced through its merger with the Russian government" (Aslund 1995: 187). As a result, government spending (along with the government) shrank enormously in one year. Russia also moved to curtail credit: "The refinance rate was only 20 percent per annum at the beginning of 1992. It was raised to 50 percent per annum that April and to 80 percent per annum in June" (Aslund 1995: 188). In an endnote, the author writes, "These official rates are not properly compounded. The official interest ... rate of 80 percent ...was actually 117 percent per annum" [note 6]).

Liberalization was accomplished equally swiftly. "Price liberalization was imposed through a presidential decree of December 3, 1991, 'Measures to Liberalize Prices,' which [stated] that 'on January 2, 1992 [the Russian Federation would undertake] the basic transition to free (market) prices and tariffs formed under the influence of demand and supply' on producer goods, consumer goods, services and labor... [The plan] took place as announced on January 2, 1992” (Aslund 1995: 140). Similarly, “a substantial liberalization of foreign trade went into effect in January 1992 ...," even if this was less 
than desired. The state trading monopoly was also abolished (EBRD 1999: 258). Six months after Gaidar's stabilization and liberalization measures were implemented, a mass privatization program relying on citizen vouchers was launched in June of 1992. "By July of 1994, 15,052 medium and large-scale enterprises, employing more than 80 per cent of the industrial workforce, had been privatized ...” (EBRD 1996: 169). This was far and away the largest transformation of property in history.

Russia's horrid performance is in sharp contrast to the spectacular growth in China in this same period. China achieved stunning success despite the fact that it carried out none of the three elements of Shock Therapy. Rather than pursue radical capitalist reforms, China implemented an agrarian reform in 1978 that transferred the control of land to peasant households (with long-term leases) and allowed them to market their production after meeting state quotas. Combined with 1984 reforms allowing the formation of village and township enterprises (VTEs), dynamic rural industrialization took off. These VTEs were marketized firms with hybrid ownership patterns (part local state, part private ownership) (see Nee 1992; Walder 1995; Oi 1999). The VTEs, combined with significant flows of FDI, more than $70 \%$ of it from Taiwan and Hong Kong, created a large group of export-oriented labor-intensive manufacturers (Naughton 1997: 11).

Privatization of large SOEs began only in 1994, after a large class of domestic capitalists already exists. Local governments adapt the speed of privatization, and local welfare policies, to minimize negative externalities. As a result, rapid large-scale privatization is normally carried out only in those areas where there are many private firms, so that the economic disruption (such as unemployment) is minimized (Cau, 
Quian, and Weingast 1997: 15; Naughton 1998: 276). Instead, many SOEs have been "corporatized" or turned into Joint Stock Companies. Typically, the government (through the treasury remains the biggest shareholder, while other state-owned investment institutions also have large blocks of shares. In spite of this momentous change, by 2002 only a tiny fraction of SOEs had been privatized.

By growing a capitalist sector from below, China developed a mixed economy in the course of two decades. Price liberalization proceeded in connection with the growth of the unplanned private and VTE sectors. It began in agriculture in 1978, with peasants allowed to sell their surplus production for market prices once they met their quota to the state at fixed prices. As these reforms proved effective, they were extended to the rest of the economy, so that SOEs could sell their output that was above the requirements of the plan at market prices. As the non-planned sector grew, more and more of the economy was free of price controls (McKinnon 1995: 98). Thus, China has "grown out of the plan," in Naughton's apt phrase (1995). Prices in the planned sector were also gradually rationalized to reflect the market price; by the early 1990 s, more than $70 \%$ of prices were decontrolled, up from 10\% in 1981 (McKinnon 1995: 104).

Trade liberalization was handled in the same manner, with special economic zones set up in Guangdong (these were connected to Hong Kong trade). In these zones, which became numerous and spread along the coast, "exporters could retain all of the foreign exchange earnings while having freer access to imported materials and foreign capital or trading services" (McKinnon 1995: 99). By the 1990s, "the difference between 'special economic zones' and the rest of the economy had been eroded" (McKinnon 1995: 99). Finally, even though China managed to avoid the hyperinflation that had 
devastated Russia after liberalization, it did so not because of the implementation of monetarist stabilization policies. Broad money, which includes printed money plus easily available credit, "[ $\mathrm{H}]$ as been very high -- averaging about 23 percent per year for more than a decade" (McKinnon 1995: 107).

The contrast between Chinese and Russian performance couldn't be more stark. Measured in 1995 US\$, GDP per capita shrank by 35\% in Russia and expanded by $137 \%$ in China. Male life expectancy during the period from 1991 to 2000 declined by five years in Russia and grew by two years in China. By the late 1990s, Russia was losing about $\$ 40$ billion a year in official and unofficial capital flight, about equal to the amount of FDI flowing into China. Indeed, China has had the best growth in the world since starting its reforms, while Russia (along with other postcommunist countries) has experienced the greatest peacetime decline ever recorded (Stiglitz 2002).

Neoliberals could dismiss the Russian-Chinese comparison by arguing that the "advantages of lateness" are actually much more important than economic policy, and that they account for the observed difference between East Asia and the rest of the postcommunist world (see Parker, Sachs, and Woo 1994). As Table 2 indicates, China and Russia had two very different starting points. China was experiencing not only a transition to a more capitalistic economy but a transition to an industrial society as well. The argument is that a very large gain in labor productivity occurs as people leave ultralow-productivity traditional agriculture for rural industrial production. The late industrializer is able to combine super-cheap labor with recent, if not the newest, technological production methods (the "trailing edge" technologies and industries). This gives exporters enormous price advantages in international markets, allowing them to 
earn hard currency to fund the purchase of technology for further labor-productivityenhancing investments (and further exports).

In addition, the communists lost power in Russia, whereas the Chinese Communist Party is alive and well after crushing the democracy movement at Tiananmen Square. Competitive elections might arguably make a difference, as special interests could exert influence to weaken necessary reforms. Alternatively, competitive elections can reduce corruption by making politicians accountable, and thereby contribute to growth. However, looking at the diversity of political outcomes in the postcommunist world (Table 2), we see that China and Russia are actually on a continuum. Belarus and the Central Asian countries are dictatorships, while Russia, Ukraine, and many of the countries of southern Europe are best understood as semi-authoritarian regimes (McFaul 2002). Similarly, the communists in China are well on their way to being just another dictatorship, as communist ideology becomes hollowed out, as typified by the invitation of private entrepreneurs into the Party.

Still, because countries in different regions have very different histories and may well be operating in very different environments, comparisons between countries in different regions makes it more difficult to discern causality. It is therefore useful to compare postcommunist countries in the same region. This provides a very rough control for a host of variables that can affect economic performance, such as geographical proximity to the advanced core, geopolitics, culture (or religion), level of development, political stability, and strength of democracy. For this reason, these comparisons are perhaps the most compelling demonstration of the dangers of Shock Therapy. 
The following comparisons, as well as the coding of policy variables in Tables 1 , 3, 4, and 5, are based on the sources listed in the historical narratives in Appendix 1.

\section{The Central European Cases Compared}

It is rather remarkable that the Czech Republic has had the lowest economic growth in the region (see Table 1), a meager one percent in 10 years, despite the fact that it was the most developed country in the region (excluding tiny Slovenia), obtained the largest amount of FDI per capita, had a very low level of external debt, and had the historical legacy of being the industrial heartland of the Austro-Hungarian empire. Because of these advantages, the fact that the Czech Republic pursued the most ambitious mass privatization is a gigantic problem for advocates of the full neoliberal package. In Poland and Slovenia, the legacy of worker organizations prevented the rapid privatization of large socialist-era enterprises. In the Slovak Republic, Vladimir Meciar, at the time the bête noire of the West, canceled the second wave of voucher privatization after the split with the Czech Republic. Thus, Slovakia experienced a significantly smaller privatization shock than the Czech Republic.

The argument advanced in this paper about the negative effects of mass privatization on state capacity (bureaucratization) is similarly supported by the Central European comparison. As is clear from Table 4, the Czech Republic records a lower value for the EBRD's indicator of state capacity, and has by far the largest increase in recorded crime. The greater insecurity of property rights relative to its neighbors should be deeply troubling to the neoliberals as well. Since the Czech Republic is as democratic as other countries in the region, it is quite plausible that this is the direct result of the 
greater privatization shock experienced in that country. As Table 3 clearly shows, the Czech Republic also had the smallest level of capital formation, the greatest decline in government consumption, and the greatest decline in the number of scientists and engineers in R. \& D., in spite of its very high level of FDI. If not for the Czech Republic's privileged location and history, which enabled this high level of FDI, its economic performance would have been substantially worse.

The Central European cases are also interesting when assessing the role of FDI in the transition. In comparison to the FSU, there are much higher levels of FDI overall, and thus a much greater export of Western capitalist property relations. This does not favor the neoliberal position, however, because even if FDI is a consequence of pro-FDI (presumably neoliberal) policies, a position that is very difficult to sustain empirically, ${ }^{10}$ the fact remains that in Central Europe the developmental outcome is the opposite of the neoliberal expectation. That is, even if high levels of FDI accrue to countries with more neoliberal policy regimes, thus far this has not balanced out the negative effects of the Shock Therapy package -- especially mass privatization.

\section{Eastern Europe: Bulgaria and Romania Compared}

Both Romania and Bulgaria pursued a good deal of Shock Therapy, although only Romania implemented a significant mass privatization program. As Table 1 shows, Romania, the more complete neoliberal reformer, performed slightly more poorly than Bulgaria. ${ }^{11}$ Not only did it have worse growth; it had a sharper increase in poverty, and a much greater fall in kindergarten enrollment rates. And, as my neoclassical sociological theory would predict, Bulgaria had a relatively stronger state than Romania on all four 
indicators (although the difference in property rights is too small to be significant) (Table 4). Still, in both countries, generally, economic performance has been terrible, somewhere between the central Eastern European nations and the Former Soviet Union. This is partially explained by the higher level of integration that Bulgaria and Romania had in the CMEA relative to the central Eastern European cases (Table 2) and their inability to attract FDI (cumulative net FDI inflows per capita 1990-2000 were only $\$ 403$ in Bulgaria and \$292 in Romania). ${ }^{12}$

Overall, Shock Therapy advocates would have a tough time explaining Bulgarian and Romanian performance. If they claim that stabilization and liberalization policies are enough Shock Therapy to be responsible for growth in Poland, they will have a hard time explaining why these policies did not produce more growth in Romania and Bulgaria. Neoliberals would claim, especially in Bulgaria, that the policies did not work because they were not implemented consistently. However, Poland also reversed many of the neoliberal policies of the Balcerowicz program after 1993 without damaging Poland's performance. Indeed, growth took off only after policy was changed following the election of a left-wing government that had an explicitly interventionist policy (see Kolodko and Nuti 1997; Snadjer and King 2002).

\section{European States of the Former Soviet Union}

The pattern found in Central and Eastern Europe also appears to hold among the successor states of the Former Soviet Union. The neoliberal explanation would predict that, all things being equal, those successor states which pursued more Shock Therapy 
would perform better than those which performed less Shock Therapy. Here, again, the comparative evidence disconfirms the neoliberal position.

Russia, as discussed above, had a triple dose of Shock Therapy. Belarus, under the anti-Western populist Alyaxandar Lukashenka, had none of the three components. Belarus's average rate of growth per capita was a poor $-0.5 \%$, but Russia, which adhered far more stringently to neoliberal prescriptions than Belarus did, had a $-3.5 \%$ growth rate in the same period, six times as big a fall. Ukraine's transition policies were somewhere between Russia's and Belarus's, but much closer to the former. Ukraine clearly had enough Shock Therapy that neoliberals would predict much higher growth than in Belarus. Again, the record is inconsistent with the neoliberal position: average GDP per capita shrank by an amazing $7.5 \%$ per year from 1991 to 2000 .

The relationship between neoliberal policy (especially mass privatization) and state capacity follows the same pattern as in central Eastern Europe. Belarus is superior to Russia and Ukraine on three of the four indicators of state capacity. The only exception is Russia's lower crime rate, but this is probably a consequence of underreporting in Russia, as discussed above.

\section{Central Asian States of the Former Soviet Union}

Let us take a final look at the last two large successor states, both part of Central Asia: Kazakhstan (population: 16 million) and Uzbekistan (24 million). Kazakhstan was the star reformer of Central Asia, and implemented all three of the postcommunist reforms. Despite this fairly close adherence to the Shock Therapy package, the economy shrank by $2.5 \%$ a year. Uzbekistan pursued a transition policy that was much more at 
odds with neoliberal prescriptions, implementing none of the neoliberal package. Yet Uzbekistan's GDP per capita decreased an average of $2.0 \%$ a year, $25 \%$ less than the decline in Kazakhstan (this despite the high level of FDI drawn to Kazakhstan's oil reserves). In Kazakhstan, a quarter of this growth occurred in 2000, when there was a dramatic increase of $10 \%$. This growth followed a huge spike in oil prices in that year (\$28 per barrel, compared with only \$10 per barrel in February 1999 [UNCTAD 2001: 294]).

From 1991 to 2000, poverty in Kazakhstan increased by 1300\%, compared with $160 \%$ in Uzbekistan. Even the decline in kindergarten enrollment was more than three times as great (see Table 1). Similarly, in the indicators for which both countries have data, Uzbekistan has much higher state capacity than Kazakhstan (see Table 4). This

outcome is, from the neoliberal perspective, quite unlikely, and is all the more surprising because of Kazakhstan's far more favorable starting point. Kazakhstan was much more developed and better educated, and marginally less integrated into the CMEA system (Table 2).

Table 5 summarizes the neoliberal reforms carried out in the 14 countries, as well as the key initial conditions and the outcomes of growth, state capacity, and security of property rights. It is clear that in every region except in East Asia the countries that came the closest to the neoliberal blueprint (often because they carried out mass privatization schemes) had worse growth performance, less state capacity, and weaker property rights. This finding is even more striking considering that in three of the regions the most neoliberal states also had significant advantages. The Czech Republic had a high level of development, low debt, and low dependence on the CMEA. Only Slovenia had a higher 
GDP, but it also lost the huge Serbian market. Bulgaria had far higher external debt than Romania. In the European FSU, Russia was, compared with Belarus and Ukraine, advantaged in terms of initial starting position and the impact of the breakup of the CMEA. And Kazakhstan was far more advantaged than Uzbekistan, without even considering its oil reserves.

In East Asia, Vietnam, the country with the closer adherence to Shock Therapy, grew at only $60 \%$ of the rate that China grew. Because countries in this regions are also undergoing a transition to industrialization, China was disadvantaged compared with Vietnam. Vietnam was even less industrialized, and started its reforms a decade later. Unfortunately, the comparison of Chinese and Vietnamese state capacity is complicated by missing data. Taxation as a percentage of GDP measure of state capacity is much lower in China than in Vietnam, but China's giant size and enormous growth makes this measure potentially very misleading. China has grown so fast that the government still increased its revenues faster than all the other countries in the comparison, and, as Table 3 indicates, it had the greatest gain in government consumption by far. By all accounts, its bureaucracy is fairly well functioning, and a command issued by the Standing Committee of the Politburo will be carried out in the most remote village in short order. And, as measured by perceived enforcement of contracts and property rights, China is among the best performers in the postcommunist world.

\section{Inconsistent Data}

Before concluding, let me preemptively address some of the cases that readers might have noticed which don't seem to fit the pattern of causality implied in my model. 
The first thing about these outliers is that they underline the number of variables affecting economic outcomes. As a result, there is bound to be a lot of unaccounted-for variance. One major uncaptured variable concerns the historically contingent development of different leading sectors at different points in time. Thus, a country's economic success will in part be determined by the dynamics of the particular global markets they are most embedded in. Furthermore, there are likely to be significant uncaptured political variables. Things like "the balance of political power" (both domestically and geopolitically) are very difficult to measure in any kind of reliable way, although this balance of power undoubtedly has an impact on economic actors in myriad ways. As a result of this complexity, we should not be surprised that all indicators do not line up perfectly for any theory, either neoliberal or neoclassical sociological. The claim of this paper is that, in terms of economic growth, human welfare, and state capacity (summarized by Table 5), the data is far more consistent with the sociological theory than with the neoliberal theory. 
Table 5: Economic Policy, Growth, State Capacity, and Property Rights

\begin{tabular}{|c|c|c|c|c|c|c|c|}
\hline & $\begin{array}{l}\text { Neoliberal } \\
\text { Reforms } \\
\text { SP/SL/SS }\end{array}$ & $\begin{array}{l}\text { GDP Per } \\
\text { Capita } 1990 \\
\text { in constant } \\
1995 \text { US\$ }\end{array}$ & $\begin{array}{l}\text { Trade with } \\
\text { CMEA as \% } \\
\text { GDP } 1990\end{array}$ & $\begin{array}{l}\text { External } \\
\text { Debt } 1989 \\
\text { Per Capita } \\
\text { current US\$ }\end{array}$ & $\begin{array}{l}\text { Avg. GDP } \\
\text { Per Capita } \\
\text { Change } \\
\text { 1991-2000 } \\
\text { (in 1995 } \\
\text { US\$) }\end{array}$ & $\begin{array}{l}\text { EBRD } \\
\text { Governance } \\
\text { Index (1-3) } \\
1999\end{array}$ & $\begin{array}{l}\text { Insecure } \\
\text { Property } \\
\text { Rights } \\
1999\end{array}$ \\
\hline Czech & SP/SL/SS & $\$ \$ 5,270$ & $\overline{6.0 \%}$ & $\$ \$ 636$ & $\overline{0.1}$ & 1.59 & 23.3 \\
\hline Slovakia & SL/SS & $\$ 4,048$ & $6.0 \%$ & $\$ 365$ & 0.4 & 1.65 & 14.0 \\
\hline Poland & SL/SS & $\$ 2,990$ & $8.4 \%$ & $\$ 1,134$ & 3.7 & 1.69 & 10.3 \\
\hline Hungary & SL/SS & $\$ 4,857$ & $13.7 \%$ & $\$ 2,040$ & 1.3 & 1.98 & 12.0 \\
\hline Slovenia & SL/SS & $\$ 9,659$ & $4.0 \%$ & NA & 1.9 & 1.95 & 11.4 \\
\hline Russia & SP/SL/SS & $\$ 3,666$ & $11.1 \%$ & $\$ 364$ & -3.5 & 1.16 & 41.6 \\
\hline Belarus & & $\$ 3,057$ & $41.0 \%$ & NA & -0.5 & 1.57 & 30.4 \\
\hline Ukraine & SP/SL/SS & $\$ 1,969$ & $23.8 \%$ & $\$ 11$ & -7.1 & 1.24 & 44.0 \\
\hline Kazakh. & SP/SL/SS & $\$ 1,995$ & $20.8 \%$ & $\$ 2$ & -2.5 & 1.27 & 31.0 \\
\hline Uzbek. & & $\$ 611$ & $25.5 \%$ & $\$ 3$ & -2.0 & 1.83 & 9.6 \\
\hline Romania & SP/SL/SS & $\$ 1,702$ & $16.8 \%$ & $\$ 473$ & -1.8 & 1.07 & 21.6 \\
\hline Bulgaria & SL/SS & $\$ 1,716$ & $16.1 \%$ & $\$ 1,126$ & -1.4 & 1.38 & 20.0 \\
\hline China & & $\$ 349$ & $2.3 \%$ & $\$ 40$ & 9.0 & NA & 11.0 \\
\hline Vietnam & SL/SS & $\$ 206$ & $15.0 \%$ & $\$ 319$ & 5.5 & NA & NA \\
\hline
\end{tabular}

SP $($ Shock Privatization $)=$ Privatized at least $25 \%$ of large SOEs under a mass privatization program within two years.

SL $($ Shock Liberalization $)=$ Liberalized at least $75 \%$ of imports and domestic prices within two years. SS $($ Shock Stabilization $)=$ Implemented an IMF approved stabilization package.

Source: Historical summaries and previous tables.

Still, we should closely examine the data that doesn't fit neatly into the causal theory traced above, and see if any patterns are revealed. The majority of surprising findings are found in Table 3, on enterprise restructuring. The relevant part of the theory for this table is that Shock Therapy induces (1) barter, (2) overdue wages, (3) a decrease in investment, (4) a decrease in government spending, and (5) a decrease in highly educated skilled manpower. It is clear from Table 3 that these processes are going on to a 
large extent in many of the postcommunist countries. To the extent that these are above all else "survival strategies" of firms, and that all firms in the postcommunist world suffered severe economic dislocation (if by nothing else than the collapse of their core: Russian inputs and markets accessed through the CMEA system), this data is consistent with the overall causal story traced above.

Close scrutiny of the data, however, reveals what appears to be some strange outcomes. For example, the Central European prevalence of strategies of non-market withdrawal is surprising. In particular, the Czech Republic's and Hungary's much lower measurements of these practices than Slovakia, Slovenia, and Poland. In this case, the differences in the structure of property among the cases account for this apparent anomalous pattern, because different types of property have different propensities for engaging in this type of activity.

Slovenia, Slovakia, and Poland had high levels of state ownership of large enterprises, and more modest levels of foreign ownership, compared with Hungary and the Czech Republic. Research in Hungary (Toth 2001) indicates that firms with foreign ownership are much less likely to tolerate inter-enterprise arrears, and do not make late payments to employees, taxes, or other firms. Large SOEs, by contrast, are likely to find it relatively easy to engage in these practices, because they have the same network links to managers at other SOEs that served for this type of "horizontal" exchange in the socialist period. The state is also likely to tolerate such behavior, when it is advantageous for "their" firms to do this. Thus, the much higher levels of FDI in Hungary and the Czech Republic and corresponding lower levels of large SOEs probably overwhelm the impact of Shock Therapy on these indicators by 1999. 
The only other indicator in the Central European group which seems surprising is the very high level of erosion of the human capital base in Slovenia and Slovakia compared with Hungary and Poland, as measured in the change in the number of scientists and engineers in R. \& D. In Slovakia's case, sectoral effects are probably at work. The split with the Czech Republic left Slovakia with most of the military industrial complex, a sector whose market (Soviet and Czechoslovak military purchases) all but disappeared. Political commitments prohibited finding alternative markets for these weapons. Thus, much of Slovakia's R. \& D. capacity would necessarily be eliminated, with daunting chances for real civilian conversion.

Another factor at work, quite possibly in Slovenia, is that this indicator also indicates brain drain -- the migration of those with scientific training to Western Europe. Bulgaria, the overall outlier on this indicator $(-71 \%)$, is probably catching the exceptionally large brain drain that occurred from that country (more than $10 \%$ of Bulgaria's population, and a higher proportion of the educated workforce, emigrated [Stiglitz 2002: 154]). Slovenia, given its proximity to Western Europe and the rise of trade with Europe in the late 1960s, had a long-established practice of "labor contracting" in the West. Once real labor markets were established, and technical personnel were free to work anywhere they wanted, it would not be surprising if many found employment right next door in Italy or Austria.

Overall, there is not a very tight fit between pursuing Shock Therapy policies and these indicators of enterprise restructuring, for all of the reasons stated above. This is not really surprising. Things like barter arrangements, and especially inter-enterprise arrears, in the Central European context, for example, might not be terribly inefficient and "non- 
rational" given the more substantial state capacity in the region. By the late 1990s, these practices could simply be functional replacements for things like inter-firm trade credits in the West (Shaffer 2000).

There are only a couple of outliers remaining. Vietnam's higher change in capital formation compared with China's is explained by Vietnam's lower starting point at the beginning of its reforms in the late 1980s, about a decade later than China's first major reforms. Export-led takeoff in a very poor agricultural society means that increases in investment will be proportionally higher, even though overall investment is less.

The final outlier in the table is the change in final government consumption in Bulgaria compared with Romania. This apparent anomaly isn't such a problem. First, the difference between Bulgaria and Romania in terms of neoliberalism is fairly small, despite Romania's being coded as implementing a mass privatization program. Romania had the smallest program coded as "mass privatization" -- covering around $25 \%$ of SOEs. Thus, differences between these indicators in these two countries might reflect other factors relatively more than in the other comparisons. Second, Romania pursued policies that were much less monetarist, when measured in annual increases in broad money (Romania increased M2 -- money plus credit -- significantly more than Bulgaria did in all but one of the years that the World Bank recorded this data [World Bank 2002]). To the extent that this spending funded government consumption (i.e., Romania reaped an inflation tax), this accounts for the difference.

Despite a lot of noise in the tables, the relationship of Shock Therapy to measures of growth, human welfare, and state capacity have a much tighter fit with sociological 
theory than with neoliberal theory (as seen in Tables 4 and 5). On these comparisons, its superiority to neoliberal theory is established.

\section{Conclusion}

The market was not an adequate substitute for a developmental state, and therefore the insertion of the postcommunist states into the global capitalist economy resulted in de-industrialization, de-modernization, and widespread impoverishment. As Sachs suggested, markets do spring up as soon as state bureaucrats vacate the field, only they spring up in low-tech small and medium-sized businesses with some type of "natural protection" (e.g., the high cost of shipping furniture means that there is a furniture industry in virtually every country). This produces a capitalist economy dominated by a few politically connected financial-industrial groups centered on the exploitation of raw materials; a relatively small, poorly paying, and non-dynamic small and medium-sized enterprise sector; and a huge base of "kiosk" capitalism and various types of petty-trading and self-provision strategies. This is nothing less than a "great leap backward" moving most of the postcommunist world closer to the Third World than to Europe. Only those countries that violated neoliberal precepts or were able to re-industrialize on the basis of very large flows of FDI avoided this fate. This finding presents a very large paradox for the neoliberals. They believe that Shock Therapy will allow the free market to create a liberal capitalist society. Rather, the application of the neoliberal transition program results in a less liberal outcome.

We can see this when comparing Poland and Russia. According to the EBRD, on a scale of 1 to 10, with 10 being the most liberal, Russia is a 2 and Poland an 8 (2000: 21). And few analysts would disagree that Poland's economy is far closer to the "liberal 
capitalist" societies found in Western Europe. Many analysts take this to mean that Poland has been far more faithful to neoliberal policy advice than Russia has. However, the fact that Poland is more "liberal" than Russia in 1999 is not the same thing as saying that neoliberal strategies work better than statist and gradualist ones. As measured by the speed of liberalization, the severity of stabilization, and the extent of rapid large-scale privatization of SOEs via mass privatization, Russia was far more neoliberal than Poland, at least up through the mid-1990s. By 1994, all three major reforms were implemented in Russia, and Poland was acknowledged to be more of a protectionist, a less stringent monetarist, and a much slower privatizer than Russian (see Appendix 1; see also Murell 1993; Stiglitz 2002: 181-2; see also comments to this effect by Sachs and Lipton 1992 and Aslund 1995).

Thus, neoliberal policies, when really implemented, have the opposite effect than what was intended. We can see this in many areas. A clear example is in monetary policy. Neoliberals want tight money and high interest rates in order to limit the amount of money circulating, and thereby to control inflation. However, in Russia, these monetarist policies contributed to financial crises for firms, with the response being the rise of barter and inter-enterprise arrears and the production of local monies. This in turn induced the federal government to print more money, in order to try to "re-nationalize" the economy (Woodruff 1999). Time-series data shows that increases in inter-enterprise debt correlate with an increase in tax non-remittance, as well as with an increase in the supply of broad money (Bernstam and Rabushka 2002: 6). Therefore, to the extent that Shock Therapy damages firms, this damages state revenues, forcing the state to print money to cover the deficit, thereby inducing inflation. In other words, enterprise failure 
in Russia produces a stream of events that produces the opposite monetary effect than the neoliberals intended. Thus, extreme neoliberal transition programs are likely to create havoc, causing changes in the state and the economy which are distinctively nonliberal.

In retrospect, we can see that Sachs, perhaps the most visible intellectual leader of the neoliberal vanguard, had got it half right back in the early 1990s: "At the base of all of this transformation [is] ... the idea ... that the postcommunist world has the potential to grow more rapidly than the develop[ed ${ }^{13}$ world and thereby to narrow the gap in living standards, if they harmonize institutions and join their economies to the global economic system" (Sachs 1994: 25. Emphasis in original). Unlike some formulations that equate globalization with neocolonial exploitation in the tradition of world systems analysis (Chussodovsky 1997; Gowan 1999; Ander and Summers 1998), the sociological analysis I offer suggests that postcommunist economies should "join their economies to the global system." The ability of Central European states to attract foreign investment and to export manufactured goods to Western Europe has allowed them to avoid the fate of the FSU and Eastern Europe. The disagreement with the neoliberals from the neoclassical sociological position sketched here is that, "if they harmonize institutions" along the lines laid out by the IMF and the World Bank, they initiate their own demodernization, making sure that they join the global economy not as equals but as deindustrialized and substantially poorer economies with less effective states.

While this analysis has emphasized Shock Therapy's developmental pathologies, we must also acknowledge that the postcommunist countries needed economic reforms. State socialism was in a long-term economic crisis, even if the actual breakdown of communist regimes is best understood as a legitimacy crisis (Szelenyi and Szelenyi 
1995). Arguably, the postcommunist countries needed to do two things. First, they needed to increase incentives for economic agents to be efficient. Second, they needed to have a rough fiscal/monetary balance. That is, they could not indefinitely continue to spend substantially more money than they earned, lest they ignite hyperinflation. However, there were many different ways in which these changes could have been made besides Shock Therapy. Privatization is not the only way to increase incentives to be efficient. Long-term leases, hybrid property forms, and promoting a small and mediumsized enterprise sector without privatizing large enterprises can be a superior alternative. The postcommunist countries could have taken the Keynesian approach of lowering interest rates and increasing government spending during downturns rather than pushing more austerity measures when their economies contracted. They could have adopted selective protection, gradual marketization, and industrial policy. And, indeed, the most successful cases, like China and Poland, did these things. This should not really be surprising, considering that the history of development since the explosion of capitalism in England has been that countries close the gap with the richest parts of the global economy not by harmonizing their institutions but, rather, by innovating their institutions, most prominently the role of the state and employer-employee relations in facilitating capitalist development (Brenner 1998).

If the transition to modern economic capitalism failed in Russia because of an improper orientation to the role of the state in the transition, one obvious conclusion of this analysis is that a strong state is needed to lead development in postcommunist societies. How one strengthens the state, let alone what the developmental strategy should be for such a state to follow, can only be a matter of speculation. We should not expect 
for there to be one approach that will work in all cases. What might be feasible and desirable for Slovenia might be quite different from what might be feasible and desirable for Russia or Uzbekistan. Large countries such as Russia and Ukraine could more plausibly attempt to follow the Korean path -- using the protected domestic market to help grow "national champions" in export industries.

The neoclassical sociological analysis implies that postcommunist states do not need a Pinochet. Simply "getting tougher" on corruption, as Putin and the neoliberals advocate -- using a strong state to enforce the neoliberal vision -- will probably be selfdefeating unless it is able to attract huge levels of FDI. Such FDI is not forthcoming in Russia or most of the postcommunist world outside Central Europe and the Baltics, and it probably never was. Relying on FDI to develop an economy, as some advocate, is a classic example of "many are called, few are chosen." It seems likely that only an industrial policy that creates some growth and stability will allow postcommunist economies to attract significant levels of FDI outside of the raw-material sectors.

Unlike Korea and Taiwan in the 1960s and 1970s, in the postcommunist world such FDI will inevitably be very important because it alone guarantees an export market for manufactured goods, and therefore makes the winning of world market share much easier. If this is true even in the giant China, this should also be true in the smaller postcommunist countries. And, while a heavy reliance on FDI isn't necessary, capturing significant world market share does seem to be necessary to close the gap with the richer countries. There are no historical cases, at least since World War II, of a country closing the developmental gap without capturing a significant share of the world market for manufactured goods (see Brenner 1998). 
Another question is of the permanence of the current postcommunist condition in the FSU and Eastern Europe -- whether this type of patrimonial capitalism is really a "new equilibrium." Many who are sympathetic to neoliberals invoke an undertheorized modernization argument: what Russia and other states are going through is an inevitable stage in the transition to capitalism, analogous to the U.S. during the reign of the robber barons. Only time will tell if this is true. However, the fact that the erosion of human capital tends to get worse over time, as disadvantages early in life (such as steep declines in kindergarten enrollment, or an increase in low birthweights) come to fruition years later, would indicate that this might not be the case. Moreover, once a grand bourgeoisie consisting primarily of competing clans of politically connected "oligarchs" has been formed (and thus the state has lost much of its bureaucratic character), it will be very difficult to lay the foundations for the growth of a new and dynamic private sector.

The sociological position is that this is ultimately a question of class formation. What is the upper class in Russia and other postcommunist countries going to look like? Are there groups of owners with an interest in entrepreneurial activity as opposed to the parasitic/rentier behavior they have displayed so far? If not, patrimonial capitalism will continue to reproduce itself, on a constantly poorer basis in the long run. In order for such a change to happen, there must be a radical change with the current structuring of power, and some historical agent capable of transforming the system or at least initiating change. Unfortunately, there appear to be no such forces on the horizon.

The working class is not likely to be such an agent. Labor in postcommunist society is not currently in a state of class formation but, rather, a profound dissolution based in the personalistic binding of workers to their failing factories for their 
subsistence, and the rise of extreme sectoral inequalities. Workers in the Russian oil industry, for example, earn far more money than employees in other sectors, and businesses in these sectors capture a growing share of the shrinking economic pie (Vorobyov and Zhukov 2000: 19).

Rather than class formation, what is emerging in most of the postcommunist world outside of East Asia and Central Europe is more a system of situses (from the Latin situ, meaning location) of competing vertical groups based in different spheres of society and the state. In Russia, for example, one of the major sectoral groups consists of firms in the oil and energy sectors. Thus, much "class action" by coal miners, for example, is better understood as situs-based action, in which workers, managers, and owners (if there are any distinct from the managers) have a coincidence of interests and act in concert.

Given these unpropitious developments, we should not expect a reversal in postcommunist fortunes anytime soon. To really reverse the de-modernization would require rebuilding a bureaucratic state. This requires securing revenue streams, and a renationalization of illegally privatized large raw-materials sectors would be a logical starting point (this would also restore quite a bit of legitimacy to the state). However, such a policy would probably need the support of the IMF and the World Bank. These organizations are unlikely to reverse their policies favoring privatization in every instance; but if they did it would require a change in the U.S. domestic scene which was big enough to change the position of the U.S. Treasury, the dominant force in these institutions (Stiglitz 2002). 


\section{References}

Amsden, Alice, Jacek Kochanowicz, and Lance Taylor. 1994. The Market Meets Its Match: Restructuring the Economies of Eastern Europe. Cambridge: Harvard University Press.

Andor, Lazlo and Martin Summers. 1998. Market Failure: Eastern Europe's 'Economic Miracle.' Pluto Press: London.

Aslund, Anders. 1995. How Russia Became a Market Economy. Washington: The Brookings Institution.

Aslund, Anders, Boone, and S. Johnson. 1996. "How to Stabilize: Lessons from PostCommunist Countries.” Brookings Papers on Economic Activity 81, 1: 217-234.

Baltowski, Maciej and Tomasz Mickanowicz. 2000. "Privatization in Poland: Ten Years After." Post-Communist Economies 12: 425-443.

Bandjel, Nina. 2001. "Embedded Economies: Determinants of FDI in Transition." Manuscript.

Baran, Paul. 1957. The Political Economy of Growth. New York: Monthly Review Press.

Bernstam, Michael S. and Alvin Rabushka. 2002. "Russia's Fiscal Pattern Redux: Testing an Old Hypothesis with the New Data." On-line edition of The Russian Economy. Hoover Institution: Public Policy Inquiry (January 9). (Available at http://www.russiaeconomy.org/coments/010902.html).

Blanchard, Oliver, Maxim Boycko, Marek Dabrowski, Rudiger Dornbusch; Richard Layard, Andrei Shleifer. 1993. Postcommunist Reform: Pain and Progress. Cambridge, MA, London [England]:The MIT Press.

Blejer, M. and F. Coricelli. Eds. 1995. The Making of Economic Reform in Eastern Europe: Conversations with Leading Reformers in Poland, Hungary and the Czech Republic. Andershot: Edward Elgar.

Brenner, Robert. 1976. "Agrarian Class Structure and Economic Development in PreIndustrial England." Past and Present 70: 30-75.

Brenner, Robert. 1977. "The Origins of Capitalist Development: A Critique of NeoSmithian Marxism.” New Left Review 104 (July-August): 25-92.

Brenner, Robert. 1986."The Social Foundations of Economic Development" in Analytical Marxism, edited by John Roemer. 1985. Cambridge: Cambridge University Press. Pp. 25-53. 
Brenner, Robert. 1998. “Economics of Global Turbulence.” New Left Review 229.

Burawoy, Michael. 1996. "The State and Economic Involution: Russia Through a China Lens.” World Development, Vol. 24, No. 6, pp. 1104-1117.

Carlin, Wendy, John Van Reenen, and Toby Wolfe. 1994. "Enterprise Restructuring in the Transition: An Analytical Survey of the Case Study Evidence from Central and Eastern Europe.” Working Paper No. 14. London: European Bank for Reconstruction and Development.

Cao, Yuanzheng, Yingyi Qian, and Barry R. Weingast. 1997. "From Federalism, Chinese Style to Privatization, Chinese Style.” Working Paper Number 126. The William Davidson Institute at the University of Michigan Business School.

Chang, Ha-Joon. 1998. "Globalization, transnational corporations, and economic development: can the developing countries pursue strategic industrial policy in a globalizing world economy.” In Dean Baker, Gerald Epstein, and Robert Pollin, eds. Globalization and Progressive Economic Policy. Cambridge: Cambridge University Press.

Chussudovsky, Michel. 1997. The Globalization of Poverty: Impacts of IMF and World Bank Reforms. London: Zed.

Collins, Randal. 1980. "Weber's Last Theory of Capitalism.” American Sociological Review 45, 6: 925-942.

De Melo, Martha, Cevdet Denizer, Alan Gelb, and Stoyan Tenev. 2001. "Circumstances and Choice: The Role of Initial Conditions and Policies in Transition Economies." The World Bank Economic Review 15, 1: 1-31.

De Melo, Martha and Alan Gelb. 1996a. "A Comparative Analysis of Transition Economices in Europe and Asia." Post-Soviet Geography and Economics (37), No. 5, pp. 265-285.

De Melo, Martha, C. Denizer, and A. Gelb. 1996b. "From Plan to Market: Patterns of Transition." Washington, DC: The World Bank.

Ekiert, Grzegorz. 2001. "The State after State Socialism: Poland in Comparative Perspective." Harvard University, Center for European Studies, photocopy.

Elson, Diane. 1991. “Is Democratic Planning Possible?” Paper presented at the Center for Social Theory and Comparative History, UCLA. Colloquium Series 1991.

European Bank for Reconstruction and Development. 1996, 1999, 2000. Transition Report. London: EBRD. 
Evans, Peter B. and James E. Rauch. 1999." Bureaucracy and Growth: A Cross-National Analysis of the Effects of 'Weberian' State Structures on Economic Growth." American Sociological Review 64 (No. 5): 748-765.

Eyal, Gil, Ivan Szelenyi, and Eleanor Townsley. 1998. Making Capitalism without Capitalists: Class formation and elite struggles in postcommunist Central Europe. London: Verso.

Filer, Randall K. and Jan Hanousek. 2001. "Data Watch: Research Data from Transition Economies." William Davidson Working Paper Number 416: 1-37.

Fischer, David. 1970. Historian's Fallacies. New York: Harper.

Fischer, Stanley and Alan Gelb. 1991. "The Process of Socialist Economic Transformation." Journal of Economic Perspectives 4: 91-106.

Fischer, Stanley, Ratna Sahay, and Carlos A. Vegh. 1996. "Stabilization and Growth in Transition Economies: The Early Experience," Journal of Economic Perspectives 10 (Spring), 2: 45-66.

Frydman, R., C. Gray, and A. Rapaczynski. 1996. Corporate Governance in Central Europe and Russia. Budapest: CEU Press.

Frydman, Roman, Andrzej Rapaczynski, and Joel Turkowitz. 1997. "Transition to a Private Property Regime in the Czech Republic and Hungary" in Economies in Transition: Comparing Asia and Europe, edited by Wing Thye Woo, Steven Parker, and Jeffrey D. Sachs. Cambridge: MIT Press. Pp.41-102.

Gligorov, Vladimir. "Republic of Slovenia: Country Report." The Vienna Institute for Comparative Economic Studies. December 1995.

Golovachev, Vitaly. 2002. "Russian Money Goes Around the World," September 13. WPS Monitoring Agency, www.wps.ru/e_index.html.

Gowan, Peter. 1995. "Neoliberal Theory and Practice for Eastern Europe." New Left Review. No. 213. Pp. 3-60.

Gowan, Peter. 1999. The Global Gamble: Washington's Faustian Bid for World Domination. London: Verso.

Graham, Thomas. "The Politics of Power in Russia." Current History Vol. 98, No. 630. Pp. 316-321.

Granovetter, Mark. 1985. "Economic Action and Social Structure: The Problem of Embeddedness." American Journal of Sociology 91, 3: 481-510. 
Greskovits, Bela. 1998. The Political Economy of Protest and Patience. Budapest: CEU Press.

Guthrie, Doug. 1997. "Between Markets and Politics: Organizational Responses to Reform in China.” American Journal of Sociology 102, 5: 1258-1304.

Hanley, Eric, Lawrence P. King, and Janos Istvan Toth. 2002. "The State, International Agencies, and Property Transformation in Post-Communist Hungary." American Journal of Sociology 108: 1 (July).

Keister, Lisa. "Explaining Growth: Business Growth Structure and Firm Performance in China's Transition Economy." American Journal of Sociology 104, 2: 404-440.

King, Lawrence P. 2000. "Foreign Direct Investment and Transition," European Journal of Sociology XLI, 2: 189-224.

King, Lawrence P. 2001a. The Basic Features of Post-Communist Capitalism: Firms in Hungary, the Czech Republic, and Slovakia. Westport CT: Praeger Press.

King, Lawrence P. 2001b. "Making Markets: A Comparative Study of Postcommunist Managerial Strategies in Central Europe." Theory and Society. Vol. 30, No. 4 (Aug): 494-538.

King, Lawrence P. 2001c. "Strategic Restructuring: Making Capitalism in PostCommunist Eastern Europe" in Managing Organizational Change in Transition Economies, edited by Daniel Dennison. Mahwah, NJ: Lawrence Erlbaum Associates. Pp.125-148.

King, Lawrence P. 2002. "Postcommunist Divergence: A Comparative Analysis of Russian and Polish Capitalism." Studies in Comparative International Development 37:3 (Fall).

King, Lawrence P. 2003. "Shock Privatization: The Effects of Rapid Large Scale Privatization on Enterprise Restructuring." Forthcoming in Politics and Society (March).

King, Lawrence P. and Ivan Szelenyi. 2003. "The Political Economy of Postcommunism." Forthcoming in The Handbook of Economic Sociology, $2^{\text {nd }}$ Edition. Edited by Richard Swedberg and Neil Smelser. New York: Princeton University Press and Russell Sage.

King, Lawrence P. and Balasz Varadi. 2002. "Beyond Manichean Economics: Foreign Direct Investment and Growth in the Transition from Socialism." Communist and PostCommunist Studies. 2(3): 1-22.

Kitsuse, J. and A.V. Cicourel. 1963. "A Note on the Uses of Official Statistics." Social Problems 11: 131-9. 
Klebnikov, Paul. 2000. Godfather of the Kremlin. Orlando: Harcourt.

Kolodko, Grzegorz and Mario Nuti. 1997. The Polish Alternative: Old Myths, Hard Facts, and New Strategies in the Successful Transformation of the Polish Economy. Helenski: UNU World Institute for Development Economics Research.

Kornai, Janos. 1980. The Economics of Shortage. Vol. 1. Amsterdam: North Holland.

Kosolowski, Rey. 1992. "Market Institutions, East European Reform, and Economic Theory." Journal of Economic Issues 26: 673-705.

Kramer, Mark. 1995. "Polish Workers and the Postcommunist Transition." Europe-Asia Studies 37 (4): .

Lipton, David and Jeffrey D. Sachs. 1990. "Creating a Market Economy in Eastern Europe: The Case of Poland." Brookings Paper on Economic Activity 1.

Lorant, Karoly. 1996. "Facts and Perspectives of the Transition in Hungary." Paper prepared for the $3^{\text {rd }}$ AGENDA Workshop on Lessons from Transformation. April 12-14, Vienna.

McDermott, Gerald. 2002. Embedded Politics. Ann Arbor: University of Michigan Press.

McFaul, Michael. 2002. "The Fourth Wave of Democracy And Dictatorship.” World Politics 54: 212-44.

McKinnon, Ronald. "Financial Growth and Macroeconomic Stability in China, 19781992: Implications for Russia and Eastern Europe" in Kazimierz Poznanski, The Evolutionary Transition to Capitalism. 1995. Boulder: Westview Press.

Mencinger, Joze. "Privatization Experiences in Slovenia." Annals of Public and Cooperative Economics 67: 415-428.

Millar, James R. 1999. “The De-development of Russia.” Current History 98 (No. 630): 322-328.

Murrell, Peter. 1993. "What Is Shock Therapy? What Did It Do in Poland and Russia?" Post-Soviet Affairs 9: 111-40.

Murrell, Peter. 1996. "How Far Has the Transition Progressed?" Journal of Economic Perspectives 10, 2: 25-44.

Naughton, Barry. 1995. Growing Out of the Plan: Chinese Economic Reform, 19781993. Cambridge: Cambridge University Press. 
Naughton, Barry. 1997. "The Emergence of the China Circle" in The China Circle: Economics and Technology in the PRC, Taiwan and Hong Kong. Edited by Barry Naughton. Washington: Brookings Institution Press.

Naughton, Barry. 1998. "China's Economy: Buffeted from Within and Without." Current History. Vol. 97, No. 620. (September): 273-278.

Nee, Victor. 1992. “Organizational Dynamics of Market Transition: Hybrid Forms, Property Rights, and Mixed Economy in China." Administrative Science Quarterly 37:127.

New York Times, 11/21/2002. “A Russian Crime Drama Deeps with Arrests.” p. A10.

Oi, Jean. 1999. "Two decades of rural reform in China: An overview and assessment." China Quarterly 159: 616-629.

Poeschl, Josef. 1996. "Special Aspects of Czech Transformation.” Final Report for the $3{ }^{\text {rd }}$ AGENDA Workshop on Lessons from Transformation. April 12-14.

Polanyi, Karl. 1944. The Great Transformation. New York: Rinehart.

Rutland, Peter. 1992-1993. “Thatcherism, Czech Style.” Telos, Vol. 94: 103-124.

Reddaway, Peter and Dmitri Glinski. 2001. The Tragedy of Russia's Reforms: Market Bolshevism Against Democracy. Washington: United States Institute of Peace Press.

Riedel, James and Bruce Comer. "Transition to a Market Economy in Viet Nam" in Economies in Transition: Comparing Asia and Europe, edited by Wing Thye Woo, Steven Parker and Jeffrey D. Sachs. Cambridge: MIT Press. Pp.189-216.

Rona-Tas, Akos. 1997. "The Czech third wave.” Problems of Post-Communism, Vol. 44 (Issue 6): 53-63.

Sachs, Jeffrey. 1991. "The Economic Tranformation of Eastern Europe: The Case of Poland." (The Frank E. Seidman Distinguished Award in Political Economy. Acceptance paper by Jeffrey Sachs). Memphis, TN: P.K. Seidman Foundation.

. 1994. Understanding Shock Therapy. London: Social Market Foundation.

. 1996a. Reforms in Eastern Europe and the Former Soviet Union in Light of the East Asian Experiences. Cambridge, MA: National Bureau of Economic Research. . 1996b. "The Transition at Mid Decade." Proceedings of the American Economic Association 86, 2: 128-33. 
Economy, Vol. 3. MIT Press.

. 2002. "The Global Innovation Divide" in Innovation, Policy and the

Sachs, J. and Lipton D. 1990. "Poland's Economic Reform." Foreign Affairs. Summer: 47-66.

Sachs, Jeffrey and David Lipton. 1992. "Prospects for Russia's Economic Reform." Brookings Papers on Economic Activity 2: 213-284.

Sachs, Jeffrey and Andrew Warner. 1996. "Achieving Rapid Growth in the Transition Economies of Central Europe.” Stockholm Institute of East European Economics, Working Paper 116, November.

Sachs, Jeffrey and W.T. Woo. 1994. "Structural factors in the economic reforms of China, Eastern Europe, and the Former Soviet Union." Economic Policy (April) 18: 10145 .

Selowski, Marcelo and Richard Martin. 1997. "Policy Performance and Output Growth in Transition Economies." American Economic Review, May (Papers and Proceedings), 87 (2): 349-53.

Schaffer, Mark. "The Non-Cash Economy in CIS," pp. 55-61 in Economic Systems, Vol. 24, No. 1, March 2000.

Shrank, Andrew and Lawrence King. 1992. "Political Capitalism." Paper presented at the Workshop in Comparative Studies, Yale University. (Available on-line at www.yale.edu/ccr.)

Skocpol, Theda and Margaret Somers. 1980. "The Uses of Comparative History in Macrosocial Inquiry." Comparative Studies in Society and History 22: 174-197.

Southworth, Caleb. 2001. "How Russian Industry Works: Worker and Firm Survival Strategies in Six Enterprises in Bashkortostan." Doctoral dissertation. University of California, Los Angeles.

Snadjer, Aleksandra and Lawrence King. 2002. "Controlled Liberalism: The State and Economic Transition in Poland." Paper presented at the North Eastern Political Science Association meeting.

Spenner, Kenneth I., Olga O. Suhomlinova, Sten A. Thore, Kenneth Land, and Derek Jones. 1998. "Strong Legacies and Weak Markets: Bulgarian State-Owned Enterprises During Early Transition. American Sociological Journal. August. Vol. 63, No. 4. Pp. 599617.

Stark, David. 1992. "Path Dependence and Privatization Strategies in East Central Europe." East European Politics and Society 6, 1: 15-51. 
Stinchcombe, Arthur. 1968. Constructing Social Theories. New York: Harcourt.

Stiglitz, Joseph. 2002. Globalization and Its Discontents. New York: Norton.

Szelenyi, Ivan and Balasz Szelenyi. 1995. "Why Socialism Failed." Theory and Society 23: 211-31.

Szelenyi, Ivan, Katherine Beckett, and Lawrence King. 1994. Handbook chapter.

Toth, Janos Istvan. 2001. "Market Environment and Production of Hungarian Manufacturing Firms.” (www.ktk-ie.hu/ tothij.)

United Nations Development Program. 1999. Human Development Report for Europe and the CIS. New York: UNDP.

UNCTAD. 2001. World Commodity Survey 2000-2001. New York: United Nations.

Vorobyov, Alexander and Stanislav Zhukov. 2000. "Russia: Globalization, Structural Shifts and Inequality" CEPA Working Paper Series I No. 19: 2-35.

Wade, Robert. 1990. Governing the Market: Economic Theory and the Role of

Government in East Asian Industrialization. Princeton, NJ: Princeton University Press.

Walder, Andrew. 1995. "Local Government as Industrial Firms: An Organizational Analysis of China's Transition Economy." American Journal of Sociology, Vol. 101, No. 2, Pp. 263-301.

Weber, Max. 1966. General Economic History. Translated by Frank H. Knight. New York, Collier Books.

Weber, Max. 1978. Economy and Society: An Outline of Interpretive Sociology. Edited by Gunther Ross and Claus Wittich. Berkeley: University of California Press.

Weidel, Janine. 2001. Collision and Collusion: The Strange Case of Western Aid to Eastern Europe. New York: Palgrave.

Williamson, Oliver. 1975. Markets and Hierarchies: Analysis and Antitrust Implications. New York: Free Press.

World Bank. 1991. Industrial Restructuring Study: Overview, Issues and Strategy for Restructuring. Washington, DC: The World Bank.

World Bank. 1996. Development Report: From Plan to Market. Washington, DC: The World Bank. 
World Bank. 1999. 2002. Development Indicators. CD-ROM. Washington, DC: The World Bank.

World Bank. 2002. BEEPS survey. (Available at http://info.worldbank.org/beeps/.)

World Bank. 2002. World Business Environment Survey. (Available on-line at http://info.worldbank.org/governance/wbes/.)

\section{Appendix 1: Historical Narratives of Economic Policies in 12 Postcommunist Countries.}

The following review of contemporary postcommunist history is very schematic and brief. This brevity is possible because, with a couple of exceptions, the facts of the matter are not actually in dispute, only the interpretation of these facts. In most of the following historical summaries, this paper relies on the same source as nearly all neoliberals: country summaries and data provided by the European Bank for Reconstruction and Development (a member of the World Bank), as well as many neoliberal authors themselves. It is hard to imagine any bias in this data running against the neoliberal position. ${ }^{14}$ Of course, non-neoliberal experts, including many of the best institutional economists from postcommunist countries, are also cited.

\section{East Asia Reform Communism}

\section{Vietnam}

Vietnam adopted agrarian reforms similar to China's starting in 1981 and continuing in 1986 and 1988 (Riedel and Comer 1997: 191). The neoliberals would predict that Vietnam should have faster rates of growth than China, because, unlike China, it adopted orthodox stabilization and liberalization policies in 1989 even if it had a similar failure to rapidly privatize state-owned enterprises (Riedel and Comer 1997: 196, 198, 203; Chussodovsky 1997: 151-152). 


\section{Central Europe}

\section{The Czech Republic}

Czechoslovakia pursued a strong Shock Therapy regime, and (the Czech portion) "is now identified as the most resolute bastion of free market ideas in Eastern Europe ..." (Frydman, Rapaczynski, and Turkewitz 1997: 87). The June 1990 election victory of Civic Forum brought with it Shock Therapy. Although Czechoslovakia did not have significant macroeconomic imbalances, they pursued a policy of "stabilizing a stable economy" (Poeschl 1996: 221). The most exceptional feature of this stabilization was the control of wages through "keep[ing] the nominal growth of wages significantly below inflation" (Frydman, Rapaczynski, and Turkewitz 1997: 63). Thus, real wages decreased by $6.3 \%$ in 1990 and 40\% in 1991 (Frydman, Rapaczynski, and Turkewitz 1997: 65).

Liberalization was pursued simultaneously with stabilization. While all prices were fixed in the neo-Stalinist regime prior to 1990, on January 1, 1991, a comprehensive liberalization was enacted, and within the year "most prices had been deregulated" (EBRD 1996: 147). Similarly, an "[a]lmost complete liberalization of quantitative controls on imports and exports was undertaken in 1991" (EBRD 1996: 147).

The Czech Republic gained most of its reputation as a leader in market reform from its innovative use of citizen vouchers to create potential owners of the large SOEs. "The whole thrust of the Czech policy was to privatize as quickly as possible, without any concern for the financial advantages of the state ..." (Frydman, Rapaczynski, and Turkewitz 1997: 86). Privatization was accomplished in two "waves." The first began in May 1992 and was over by mid-1993. Nineteen hundred large firms were privatized by a combination of vouchers and direct sales to foreign and domestic actors. In 988 of these 
firms, individuals and investment funds used their vouchers to bid on the shares of companies. This was followed by a second wave of privatization, initiated in March 1994 and completed on March 1, 1995. As a result of these two waves of privatization, "the private sector may have accounted for 75 per cent of GDP in 1996" (EBRD 1996: 146).

Thus, the Czech Republic was among the most enthusiastic and faithful of the neoliberal Shock Therapy adherents. Some have charged that Klaus was actually a pragmatist who pursued social-democratic policies and merely paid lip service to neoliberal ideas (Rutland 1992-1993). This is a fundamentally mistaken interpretation of the Czech transition. The first Czech government did provide a social safety net, but this social-democratic policy took the form of a redistribution of wealth after market-led production decisions were made. This is a likely explanation for the Czech Republic's relatively excellent performance on human development (poverty, health care, and education), as recorded in Table 1. The relevant facts are that macroeconomic policies were decidedly neoliberal. And even though the state retained some residual ownership in firms through the partial ownership of banks that in turn owned investment companies that in turn owned shares in companies, there is no evidence that the state tried to exercise this ownership (see King 2001a, Rona-Tas 1997). The state did not have the capacity to exercise these ownership rights even if it had the inclination, which it generally did not (McDermott 2001).

\section{Slovakia}

Slovakia, as part of Czechoslovakia, received the same stabilization and liberalization shocks as the Czech Republic. These policies of fiscal austerity and 
liberalization were maintained by the subsequent Slovak governments (see EBRD 1999: 264). In addition, it was still part of the federation when the first round of voucher privatization was carried out. From May 1992 to mid-1993, 750 Slovak enterprises were involved, with shares in 503 of these firms exchanged for vouchers (EBRD 1996: 172). After the Velvet Revolution, the new government canceled the second wave of voucher privatization. Citizen vouchers were exchanged for five-year bonds, which could be used for a wide variety of purposes (see EBRD 1996: 172). The government continued to privatize enterprises through direct sales, with a heavy reliance on management and employee buyouts (MEBOs), which required a down payment of $10-20 \%$, with the remainder to be paid in installments. Frequently, these payments took the form of investment in the company itself (see EBRD 1996: 172). The government has also adopted a slew of policies to support small and medium-sized enterprises, including consulting services, training programs, and some loans (EBRD 1999: 173). Thus, Slovakia's policies, in comparison with the Czech Republic's, leaned more toward building "capitalism from below," as in China, and using direct sales rather than vouchers. Even when shares were essentially given away through MEBOs, the government created incentives to ensure that new owners made investments in their companies. Indeed, if companies did not fulfill the terms of their privatization (in terms of paying for the installments -- often making investments), the government can review the privatization and reverse the privatization. "These reviews can lead to significant ownership changes and the government hopes to involve foreign strategic investors in the re-privatization process" (EBRD 1999: 262). 


\section{Slovenia}

While still part of Yugoslavia, Slovenia experienced the first dose of Shock Therapy in the region. IMF-sponsored macroeconomic reforms began in 1980, with a stabilization package, followed by another stabilization package, which included import liberalization and a freeze on investments in 1983. As the economy continued to slow, the "May Anti-inflation Programme" was initiated in 1988. In spite of these efforts to stabilize the economy, the rate of inflation shot up to $2700 \%$ in 1989 (Chussodovsky 1997: 245-6). In response, the pro-U.S. government of Prime Minister Markovic came to the U.S. to meet with President Bush, and the result was a "big bang in mid-December 1989, which served as a model for transition packages elsewhere in the region" (Amsden, Kochanowicz, and Taylor 1994: 34). The package included mostly stabilization measures, and also further liberalization, including the deregulation of the trade regime in January 1990. Real wages declined by 41\% in the first half of 1990 (World Bank 1991: viii). This was matched by a fall in output of $8.5 \%$ : "Spurred in part by the failing economy, separatist movements in the republics pushed the Federation into a brutal war" (Amsden, Kochanowicz, and Taylor 1994: 34).

Slovenia seceded in June 1991, but it managed essentially to avoid civil war (it lost only 30 soldiers). However, even before independence, "[c]omprehensive price liberalization came in 1990 at the time of the Markovic regime" (Gligorov 1995: 13). Prices were further freed up so that "[p]rice liberalization was almost complete by mid1994" (EBRD 1996: 175). Foreign trade was liberalized as well, although the Slovenian economy (as part of Yugoslavia) had experienced increasing openness since the early 1960s. Indeed, by the "mid-1980s the EC was Slovenia's main trading partner, more than 
50\% of Slovenia's foreign trade being directed to that area" (Gligorov 1995: 8).

Markovic's reforms continued this trend, so that, by the end of " 1994,98 per cent of imports were free from quantitative restrictions. The estimated rate of effective protection amounts to 4 per cent (down from 38\% before liberalization) begun" (EBRD 1996: 175).

In Slovenia, capitalism from below was actually under way before the transition, resulting in "a surge of small scale private activity already in the late 1980 s.... [T]he share of the private sector increased, though privatization was slow in coming. The private share in the GDP was about $8 \%$ before liberalization in the late 1980s and increased to about $40 \%$ (private and mixed firms together) at the end of 1994, even before privatization" (Gligorov 1995: 15, 18). Shock Therapy advocates were not able to garner enough political support to push through rapid large-scale privatization (see Mencinger 1996, Gligorov 1995 for details). The end result heavily favored firm insiders (Gligorov 1995: 16; EBRD 1998: 268). Of 1,549 companies that the government intended to privatize, only one privatization was completed in 1993, 113 by the end of 1994, and 435 by the end of 1995 (EBRD 1996: 175; Mencinger 1996: 423). However, most of these were small and medium-sized enterprises, and even in 1999 "there has been little progress in the [area] of large-scale privatization" (EBRD 1999: 266). Further violation of neoliberal precepts occurred when Slovenia established a development corporation to restructure large enterprises before privatization, and in 1999 "[a] number of large-scale enterprises in the aluminum, steel and oil sectors are sill in the rehabilitation process ...” (EBRD 1999: 266). 


\section{Hungary}

Hungary has often been described as a case of "gradualism," compared with the rapidity of liberalization in Poland and privatization in Czechoslovakia. Though slightly less radical in these respects than its most prominent Central European neighbors, Hungary still initiated "ambitious market-oriented reforms between 1989 and 1991. Comprehensive liberalization was introduced for prices and foreign trade ... the banking system became increasingly market-based and privatization was initiated" (EBRD 1996: $153)$.

"Most prices were liberalized" in January 1991 (EBRD 1999: 226). Since then, more than $90 \%$ of consumer prices are free of administrative control. Foreign trade was liberalized extremely quickly as well, from 1989 to 1991. By 1991, "licensing requirements and quotas" were eliminated in $90 \%$ of imports, up from $40 \%$ in 1989 (EBRD 1996: 154). Actually, Hungary had liberalized quite a bit under socialism, so that the rapid trade liberalization of 1991 does not mean that Hungary liberalized very rapidly overall. Rather, Hungary experienced a substantial but gradual liberalization under socialism, followed by the drastic elimination of much of the remaining trade barriers after the collapse of communism. Considering the elimination of most price controls, and the further radical reduction of prices, albeit from a relatively liberalized starting point, Hungary is coded as having a Shock Liberalization.

Hungary, because of government policy in the 1980s, was the one postcommunist country without the so-called "monetary overhang" (Amsden, Kochanowicz, and Taylor 1994: 31). Its ratio of currency and accessible bank deposits (broad money) to GDP in 1990 was only 0.4 for Hungary, compared with 0.7 in Czechoslovakia and 0.9 in Poland. 
Considering "[a] typical value in a market economy from 0.2 to 0.5 or more," Hungary was already a fairly stabilized economy (see Amsden, Kochanowicz, and Taylor 1994: 31, fn.10). Still, the victors of the 1990 election, the Hungarian Democratic Forum (in coalition with the Smallholders Party and the Christian Democrats), pursued a neoliberal stabilization.

Stabilization efforts began in 1988-1989, when the government "radically reduc[ed] subsidies" (EBRD 1996: 155). The new government introduced a tax on excess wages, and there was "tighter access to finance for loss-making enterprises" (EBRD 1996: 154). The government pursued a "tight monetary policy," resulting in interest rates that were "extremely high (30-35\%)" (Lorant 1996: 10).

Privatization, unlike in Russia and the Czech Republic, did not take the form of a voucher program. Instead, the government's main method was direct sales for cash. This began in March 1990, and "by the end of 1995 control of most of the formerly stateowned large companies had been transferred to the private sector" (EBRD 1996: 153). Indeed, most of this privatization was accomplished by the end of 1993: "In the beginning of privatization there were 1848 enterprises with 1940 billion HUF book value in the ownership of the State Property Agency. By the year 1994 [there] remained 665 firms with 253 billion HUF book value" (Lorant 1996: 15). Many of the direct sales were to foreigners, which accounts for Hungary's overwhelming early lead in attracting FDI in the transition economies (net inflow was $\$ 4,410$ million by 1995 , out of a total of $\$ 9,418$ million in Central and Eastern Europe and the Baltic states) (EBRD 1999: 4). The decision of the Hungarian communists to increase travel to, and economic integration with, Western Europe from the late 1960s apparently established networks that were 
subsequently activated by managers of SOEs, accounting for much of this early FDI (see case-study data in King 2001a, 2001b). However, it would be a mistake to characterize all privatization as taking the form of FDI, as the government also subsidized the sale of enterprises to domestic owners through special credits with real negative interest rates and the use of management and employee buyouts (EBRD 1999: 32), especially in 1994 (see Hanley, King, and Toth 2002).

\section{Poland}

Under the first postcommunist Mazowiecki government, the Balcerowicz Plan (named after the finance minister) initiated a strong dose of Shock Therapy in the beginning of 1990. There was a "drastic reduction of the money supply and the establishment of a high interest rate (exceeding inflation in real terms from March 1990)" (Balcerowicz, Blaszcyk, and Dabrowski 1998: 138). "State subsidies to enterprises were substantially reduced early in the reform programme, falling from 12.9\% of GDP in 1989 to $3.2 \%$ in 1992" (EBRD 1996: 165). In addition, wages were controlled by the Popiwek, an "excess wage tax for state enterprises, which was operating between 1990 and 1994" (EBRD 1996: 166). By January 1990, "banks were permitted freely to set deposit and interest rates. The refinancing rate on credits for central investments, which used to be the main reference rate, has been replaced by more market-oriented rates ..." (EBRD 1996: 166).

Liberalization came about very quickly: "Most prices were liberalized in 19901991" (EBRD 1996: 165). Similarly, “[i]n 1990 most tariff and non-tariff barriers to trade were suspended or sharply reduced and the state monopoly on foreign trade had ended" 
(EBRD 1996: 166). Thus, Poland has been celebrated as the showcase of the successful application of Shock Therapy. The stabilization and liberalization program, drawn up in consultation with the IMF, "was enacted on January 1, 1990” (Balcerowicz, Blaszcyk, and Dabrowski 1998: 137). Thus, there is virtually no disagreement that Poland pursued a strong stabilization and liberalization program at the beginning of its transition.

As the pain accompanying Shock Therapy became apparent, a political backlash ensued. As a result, in the summer of 1990, "fiscal and monetary policy were considerably loosened" (Murrell 1993: 129). State credits again flowed to enterprises, and began to "approach ... old levels" (Murrell 1993: 129). By the next summer, the average tariff went from 5\% to $18 \%$, and "selective protection was endorsed" (Murrell 1993: 129). In addition, the government pursued a wide range of interventions in the economy, including vertical and horizontal industrial policy (see Snajder and King 2002). Generally, Poland relied on the state, not just the market, to restructure enterprises, and actually built more state structures, especially regional economic bureaucracies. Employment in public administration more than doubled -- from 69,319 in 1989 to 171,246 in 1998 , and the number of central state agencies increased, from 32 in 1988 to 55 at the end of 1999 (see Ekiert 2001).

The third component of Shock Therapy, rapid privatization of large state-owned enterprises, was not implemented. While plans for rapid large-scale privatizations had been drawn up, they were not enacted, owing to political pressure. "With the election of a left-of-center coalition government in 1993, the pace of structural change, particularly that of privatization, slowed" (EBRD 1996: 165). Privatization has proceeded mostly in small and medium-sized enterprises; by 1995, "Most of the enterprises that changed 
ownership were small companies employing fewer than 200 employees." By 1998, the situation hadn't changed dramatically: "Privatization of the largest industrial enterprises is proceeding very slowly" (Balcerowicz, Blaszcyk, and Dabrowski 1998: 146, 160). The problem was political resistance.

The Mazowiecki government had a plan for "a quick privatization of the state sector" in 1990 (Poznanski 1992: 644), but this plan was not implemented, as public dissatisfaction and labor unrest developed. According to Mark Kramer, "growing signs of public discontent ... helped induce the government to defer its plans for mass privatization of large enterprises" (Kramer 1995: 654). Rapid large-scale privatization continued to be too risky politically for subsequent governments. Thus, privatization in Poland occurred primarily through the growth of new businesses from the ground up: "reentry of private ownership ... has proceeded mostly through the formation of new

private businesses" (Poznanski 1996: 279). Since 1996, however, there has been a steady increase in the privatization of already restructured SOEs to foreign capital (see King 2002).

\section{Romania and Bulgaria}

If the experience of central Eastern Europe lends no support to neoliberal theory, what about the other relatively large countries of Eastern Europe that were spared the trauma of civil and ethnic war? The experiences of the two largest such countries, Romania and Bulgaria, also fail to confirm neoliberal expectations. 


\section{Bulgaria}

Bulgaria started with a healthy dose of Shock Therapy. There was a "sweeping liberalization of prices in $1991 \ldots$... [at the same time as] imports were significantly liberalized" (EBRD 1996: 143). However, by 1993 the price liberalization began to be partially reversed, in efforts to try to control inflation. Stabilization policies included "ceilings on the annual percentage increase in the wage bill of state enterprises.... These

ceilings have not allowed wages to keep pace with inflation" (EBRD 1996: 143). In 1997, a "comprehensive stabilization" program centered on a currency board was introduced with the support of the IMF (EBRD 1999: 202).

Large-scale privatization, which was formally initiated in 1993, proceeded very slowly, "with only 6 per cent of total state enterprise assets privatized by mid-1996" (EBRD 1996: 142). After 1996, however, a voucher-based mass privatization program "modeled largely on the Czech scheme" was created (EBRD 1996: 142). The first round was held in October 1996 and the second round in January 1999. However, by the middle of 1999, only a few large enterprise privatizations were completed (EBRD 1999: 202).

\section{Romania}

In Romania, “[r]eforms began in November 1990 with radical price liberalization ..." (EBRD 1996: 167). This consisted of eliminating half of all administered prices in one shot (from $85 \%$ to $47 \%$ ), followed by additional steep reductions over the next two years, to $29 \%$ and then $20 \%$ (EBRD 1999: 256). This price liberalization was matched by trade liberalization when "[m]ost licensing requirements for export and import were eliminated in May 1992, leaving quantitative import restrictions only for a few products 
related to public health or safety. There are no duties on exports, and the tariff treatment of non-agricultural imports is fairly liberal" (EBRD 1996: 168). Only agriculture remains heavily protected.

Romania was also already fairly "stabilized" at the beginning of the transition. Broad money was $46.9 \%$ of GDP in 1991, but this was reduced to $30 \%$ in 1992 and 22.3\% in 1993 (EBRD 1999: 257). Thereafter, "[f]rom mid-1993 onwards, a serious effort was made to tighten credit policy, and thereby the broad budget constraint facing enterprise" (EBRD 1996: 167).

Only in privatization was Romania seriously lacking, according to the neoliberal criteria. Mass privatization legislation was formally initiated in September 1991 (EBRD 1999: 254), but this affected mostly small and medium-sized enterprises. In 1996, the private sector accounted for only 16\% of total employment in industry (EBRD 1996: 167). However, a "comprehensive scheme of mass privatization was launched in earnest in 1995, after having been on the drawing board for years" (EBRD 1996: 167). Thus, large-scale privatization commenced in 1995, and out of a total of 3,900 medium-sized to large companies slated for privatization, "[b]y March 1996, more than 1,500 companies had been privatized" (EBRD 1996: 167). ${ }^{15}$

\section{Former Soviet Union}

\section{Belarus}

Of the large states of the European part of the FSU, Belarus performed the best (per capita GDP shrank by "only" an average of $0.5 \%$ from 1990 to 2000), despite the fact that Lukashenka has pursued what is, for the most part, essentially a "neo-Stalinist" 
transition strategy. The one exception was prices, which were very slowly deregulated (the share of administered prices in the Consumer Price Index was 100\% in 1990, but fell steadily to 27\% in 1997 [EBRD 1999: 196]). There has been no progress in foreign-trade liberalization and almost no progress on large-scale privatization (although there was a very small amount of voucher privatization [EBRD 1999: 194]).

\section{Ukraine}

Ukraine pursued a partial and inconsistent liberalization and austerity package until 1994, when a full big-bang approach, including a voucher-based program, was launched. By mid-1996, some 3,500 of 8,000 medium-sized and large enterprises had been privatized (EBRD 1996: 180).

\section{Kazakhstan}

Kazakhstan implemented a "comprehensive reform package" in 1993, complete with plans for mass privatization with vouchers (EBRD 1996: 156). This privatization took place starting at the end of 1994, and by early 1996 "60 percent of the total equity of 1,700 large enterprises had been transferred into private hands ...” (EBRD 1996: 156).

\section{Uzbekistan}

After an initial radical liberalization of consumer prices in January 1992, policy was reversed and "a rationing system was introduced for a wide range of goods" (EBRD 1996: 183). Prices were gradually liberalized throughout 1994 and 1995, with some key goods still regulated by the government. Trade reform was very tentative until early 
1994, when some liberalization occurred, although by 1996 export tariffs existed for 72 product groups, and range up to $100 \%$. In addition, as of 1996 , "the bulk of trade is still channeled through state-owned foreign trade companies" (EBRD 1996: 183). Finally, "restrictive trade practices" were reintroduced in 1997.

Uzbekistan was similarly cautious with privatization, so that by 1999 "[ $[$ t]he state remains the dominant owner in most industrial companies" (EBRD 1999: 282). However, small-scale privatization was extensive, and the state strongly promotes the small and medium enterprise sector (SMEs). Indeed, privatization revenues are used to fund the SME sector (EBRD 1999: 283). Thus, the state moved significantly beyond the "invisible hands" model proposed by the neoliberals. 
${ }^{1}$ Please direct all comments to the author at lawrence.king@yale.edu. I would like to thank Ivan Szelenyi, Charles Perrow, Andrew Schrank, Marcus Kurtz, Hannah Breukner, Jeff Miley, Casiano Hacker-Cordon, Valarie Bunce, and William King, for helpful comments on various drafts of this paper.

${ }^{2}$ Neoclassical assumptions are not only compatible with the anti-statist neoliberal agenda, as various market socialist schemes advocate combining markets with state ownership attest to (see Szelenyi, Beckett, and King 1994). The neoclassical sociological alternative, however, differs from the neoclassical economic theory on these core assumptions. Rather than actors without systematic information deficiencies making rational calculations, actors are seen as having bounded rationality and often very limited information. Rather than being "rational" in the economic sense of the term (utility maximizing with stable preferences), it is more accurate to say they have interests. Similarly, rather than a world of atomized individuals, in the sociological conception people only exist in various social relationships. That is, they are embedded in networks that aggregate to social structures (Granovetter 1985). As a result, the economy is characterized as people with network connections that provide unequal amounts of social power and information competing with each other (see King 2001a, 2001c (book chapter)).

${ }^{3}$ Of course, foreign direct investment can have quite deleterious effects. Elsewhere, I identify eight ways such investment leads to negative outcomes, and ten ways such investment leads to positive outcomes (King and Varadi 2002). On balance, however, the positive effects far outweigh the negative ones, at least in Hungary. 
${ }^{4}$ Of course, MNCs can "articulate" with pre-capitalist property forms by employing nonfree wage labor - in which case such investment will not produce a developmental dynamic (see Baran 1957).

${ }^{5}$ I present case study evidence from 25 Russian firms and 23 Polish firms that lend support to these arguments elsewhere (King 2002, 2003).

${ }^{6}$ There is unfortunately reason to believe that these measurements based on perception suffer from a serious selection bias. In non-bureaucratic systems, existing firms are likely to have personal connections to administrative elites, and might therefore not view these "cronyistic" elements as problematic. In more bureaucratic systems, non-connected firms are more likely to exist, and might therefore report that cronyism is a bigger problem. Only panel data would solve this problem.

${ }^{7}$ This lack of data, even of estimates, is puzzling. In many cases the IMF was intimately involved in vetting budgetary decisions, and thus must have had access to at least some estimate of revenues.

${ }^{8}$ The non-bureaucratic nature of the state results in its near abdication of enforcing contracts and protecting property rights. The regular assassination of members of the Russian government because of their "business connections" is a well known fact (NYT 2002). Similarly, the media mogul/banker/oligarch Guisinsky needed a private security force of about 1,000 men, possibly more (Klebnikov 2000: 151). Similarly, in Siberia, there were "shooting wars" over the control of aluminum companies, giving a patrimonial twist to "corporate takeovers."

${ }^{9}$ However, all three states remain heavily dependent on the export of raw materials from Russia. 
${ }^{10}$ Most FDI will depend on a host of other conditions, such as geographical proximity to advanced capitalist economies, the existence of an expatriate diaspora with capital willing to invest in the home country, personal contacts linking Western capital with local managers, the size of the local market, its valuable natural resources, its infrastructure, its human capital base (including language capacity), its wage levels, the general business climate and perhaps its cultural similarity to the country of the potential investor (see Nina Bandelj 2001). The fact that increasingly FDI-friendly policies throughout the developing world in the 1980s and 1990s have not led to significantly elevated levels of FDI (excluding China - which does not even have capital account convertability) should caution against placing too much hope on pro-FDI policy as a means of securing FDI flows. It is probable that anti-FDI policies can be very effective in keeping (or pushing) FDI out, but pro-FDI policies are very ineffective in pulling FDI in (See Chang 1998: 110).

${ }^{11}$ Romania, according to my coding, is clearly more neoliberal than Bulgaria because it actually implemented a significant mass privatization program. However, according to EBRD reports, Romania's program was the closest to the cut-off point of $25 \%$ (the next biggest was Poland's program implemented in 1995 which covered mostly medium sized firms that constituted $10 \%$ of the assets of SOEs) [Baltowski and Michanowicz 2000]. Furthermore, as indicated in the historical summaries in Appendix 1, Bulgaria's initial liberalization appears to be even quicker than Romania's. Thus, Bulgaria and Romania are very close in terms of overall adherence to Shock Therapy.

${ }^{12}$ It should be noted that these levels are still significantly above the levels in China and Vietnam on a per capita basis. 
${ }^{13}$ Sachs uses the term "the developing world" but he clearly means developed (see Gowan 1995:8), or else how would they narrow the gap with the West? It is also clear from the context of the passage. If he meant that postcommunist countries would attain rates of growth that were higher than African countries', for example, Shock Therapy would have never been compelling to anyone in the East or the West.

14 “The EBRD seeks to foster the transition to an open market-oriented economy and promote private and entrepreneurial initiative in all 26 of its countries of operation. It does this as a participant investor with a private sector focus" (EBRD 1999: iv).

${ }^{15}$ For 1996, Romania received a score of 3 on the EBRD's and World Bank's four-point scale for large- scale privatization. A 3 indicates "More than 25 percent of large-scale enterprise assets in private hands or in the process of being privatized (with the process having reached a stage at which the state has effectively ceded its ownership rights), but possibly with major unresolved issues regarding corporate governance" (EBRD 1999: 25). Without an explanation, this score was lowered to 2.7 for both 1997 and 1998 (EBRD 1999: 256). At any rate, almost 40\% of medium-sized and large enterprises were privatized, representing around $25 \%$ of total assets. 


\section{DAVIDSON INSTITUTE WORKING PAPER SERIES - Most Recent Papers}

The entire Working Paper Series may be downloaded free of charge at: www.wdi.bus.umich.edu

CURRENT AS OF 5/1/03

\begin{tabular}{|c|c|c|}
\hline Publication & Authors & Date \\
\hline No. 559: Explaining Postcommunist Economic Performance & Lawrence P. King & May 2003 \\
\hline $\begin{array}{l}\text { No. 558: Tax Structure and the FDI: The Deterrent Effects of } \\
\text { Complexity and Uncertainty }\end{array}$ & $\begin{array}{l}\text { Kelly Edmiston, Shannon Mudd } \\
\text { and Neven Valev }\end{array}$ & Apr. 2003 \\
\hline No. 557: Provincial Protectionism & Konstantin Sonin & Apr. 2003 \\
\hline $\begin{array}{l}\text { No. 556: Nominal and Real Convergence in Estonia: The Balassa- } \\
\text { Samuelson (dis)connection }\end{array}$ & Balázs Égert & Apr. 2003 \\
\hline $\begin{array}{l}\text { No. 555: Banks-Firms Nexus under the Currency Board: Empirical } \\
\text { Evidence from Bulgaria }\end{array}$ & $\begin{array}{l}\text { Nikolay Nenovsky, Evgeni Peev } \\
\text { and Todor Yalamov }\end{array}$ & Apr. 2003 \\
\hline $\begin{array}{l}\text { No. 554: To Steal or Not to Steal: Firm Attributes, Legal Environment, } \\
\text { and Valuation }\end{array}$ & Art Durnev and E. Han Kim & Apr. 2003 \\
\hline No. 553: Corporate Stability and Economic Growth & $\begin{array}{l}\text { Kathy S. He, Randall Morck and } \\
\text { Bernard Yeung }\end{array}$ & Apr. 2003 \\
\hline $\begin{array}{l}\text { No. 552: So Many Rocket Scientists, So Few Marketing Clerks: } \\
\text { Occupational Mobility in Times of Rapid Technological Change }\end{array}$ & $\begin{array}{l}\text { Nauro F. Campos and Aurelijus } \\
\text { Dabušinskas }\end{array}$ & Mar. 2003 \\
\hline $\begin{array}{l}\text { No. 551: Determinants of Interregional Mobility in Russia: Evidence } \\
\text { from Panel Data }\end{array}$ & $\begin{array}{l}\text { Yuri Andrienko and Sergei } \\
\text { Guriev }\end{array}$ & Feb. 2003 \\
\hline $\begin{array}{l}\text { No. 550: Gross Job Flows in Ukraine: Size, Ownership and Trade } \\
\text { Effects }\end{array}$ & $\begin{array}{l}\text { Jozef Konings, Olga Kupets and } \\
\text { Hartmut Lehmann }\end{array}$ & Mar. 2003 \\
\hline $\begin{array}{l}\text { No. 549: Technology Transfer through FDI in Top-10 Transition } \\
\text { Countries: How Important are Direct Effects, Horizontal and Vertical } \\
\text { Spillovers? }\end{array}$ & $\begin{array}{l}\text { Jože P. Damijan, Mark Knell, } \\
\text { Boris Majcen and Matija Rojec }\end{array}$ & Feb. 2003 \\
\hline $\begin{array}{l}\text { No. 548: Does Foreign Direct Investment Increase the Productivity of } \\
\text { Domestic Firms? In Search of Spillovers through Backward Linkages }\end{array}$ & Beata K. Smarzynska & Mar. 2003 \\
\hline $\begin{array}{l}\text { No. 547: Re-employment Probabilities and Wage Offer Function for } \\
\text { Russian Labor Market }\end{array}$ & Natalia V. Smirnova & Feb. 2003 \\
\hline $\begin{array}{l}\text { No. 546: Democratization's Risk Premium: Partisan and Opportunistic } \\
\text { Political Business Cycle Effects on Sovereign Ratings in Developing } \\
\text { Countries }\end{array}$ & $\begin{array}{l}\text { Steven Block, Burkhard N. } \\
\text { Schrage and Paul M. Vaaler }\end{array}$ & Feb. 2003 \\
\hline $\begin{array}{l}\text { No. 545: Structural Reforms and Competitiveness: Will Europe } \\
\text { Overtake America? }\end{array}$ & Jan Svejnar & Feb. 2003 \\
\hline No. 544: Why the Rich May Favor Poor Protection of Property Rights & atin Sonin & Dec. 2002 \\
\hline $\begin{array}{l}\text { No. 543: Reinvested Earnings Bias, The "Five Percent" Rule and the } \\
\text { Interpretation of the Balance of Payments - With an Application to } \\
\text { Transition Economies }\end{array}$ & $\begin{array}{l}\text { Josef C. Brada and Vladimír } \\
\text { Tomšík }\end{array}$ & Feb. 2003 \\
\hline $\begin{array}{l}\text { No. 542: The Impact of Ownership Reform in Chinese Industry, 1995- } \\
2001\end{array}$ & $\begin{array}{l}\text { Gary H. Jefferson, Su Jian, Jiang } \\
\text { Yuan and Yu Xinhua }\end{array}$ & Feb. 2003 \\
\hline $\begin{array}{l}\text { No. 541: Defensive and Strategic Restructuring of Firms during the } \\
\text { Transition to a Market Economy }\end{array}$ & $\begin{array}{l}\text { Domadenik, Janez Prašnikar and } \\
\text { Jan Svejnar }\end{array}$ & Feb. 2003 \\
\hline No. 540: Tenuous Financial Stability & $\begin{array}{l}\text { Neven T. Valev and John A. } \\
\text { Carlson }\end{array}$ & Feb. 2003 \\
\hline $\begin{array}{l}\text { No. 539: Non-monetary Trade and Differential Access to Credit in the } \\
\text { Russian Transition }\end{array}$ & Vlad Ivanenko & Feb. 2003 \\
\hline $\begin{array}{l}\text { No. 538: International Price-Fixing Cartels and Developing Countries: } \\
\text { A Discussion of Effects and Policy Remedies }\end{array}$ & $\begin{array}{l}\text { Margaret Levenstein and Valerie } \\
\text { Suslow with Lynda Oswald }\end{array}$ & Feb. 2003 \\
\hline No. 537: Foreign Banks in Bulgaria, 1875-2002 & $\begin{array}{l}\text { Kenneth Koford and Adrian E. } \\
\text { Tschoegl }\end{array}$ & Jan. 2003 \\
\hline $\begin{array}{l}\text { No. 536: Forthcoming in Vanderbilt Journal of Transnational Law, } \\
\text { "Healthy Organizations and the Link to Peaceful Societies: Strategies } \\
\text { for Implementing Organizational Change" }\end{array}$ & $\begin{array}{l}\text { Jeannette Jackson and Maria } \\
\text { Coolican }\end{array}$ & Jan. 2003 \\
\hline $\begin{array}{l}\text { No. 535: Forthcoming in Vanderbilt Journal of Transnational Law, } \\
\text { "Workplace Violence and Security: Are there Lessons for } \\
\text { Peacemaking?" }\end{array}$ & $\begin{array}{l}\text { Frances E. Zollers and Elletta } \\
\text { Sangrey Callahan }\end{array}$ & Jan. 2003 \\
\hline
\end{tabular}

